\title{
12. STABLE ISOTOPE AND GEOCHEMICAL RECORD OF CONVECTIVE HYDROTHERMAL CIRCULATION IN THE SEDIMENTARY SEQUENCE OF MIDDLE VALLEY, JUAN DE FUCA RIDGE, LEG 1391
}

\author{
Gretchen L. Früh-Green, ${ }^{2}$ Judith A. McKenzie, ${ }^{2}$ Maria Boni, ${ }^{3}$ Anne Marie Karpoff, ${ }^{4}$ and Martine Buatier ${ }^{5}$
}

\begin{abstract}
Oxygen and carbon isotope measurements on authigenic carbonates and silicates from Sites 856,857 , and 858 , drilled during Ocean Drilling Program Leg 139 at Middle Valley, Juan de Fuca Ridge, a sedimented seafloor spreading ridge, provide a record of present and past convective fluid circulation and high-temperature gradients associated with hydrothermal alteration and the deposition of massive sulfides. Oxygen isotope compositions of authigenic carbonates from the active hydrothermal field at Site 858 show vertical thermal gradients of $2.2^{\circ} \mathrm{C} / \mathrm{m}$ in distal holes (Holes $858 \mathrm{~A}$ and $858 \mathrm{C}$ ) and up to $10^{\circ} \mathrm{C} / \mathrm{m}$ at the central vent areas (Hole 858D). The higher thermal gradient is consistent with oxygen isotope data for Mg-rich authigenic clays and quartz, which yield isotope fractionation temperatures of approximately $265^{\circ} \mathrm{C}$ at $32 \mathrm{mbsf}$ in Hole $858 \mathrm{~B}$. Extrapolation of this latter gradient to greater depths indicates temperatures of approximately $400^{\circ} \mathrm{C}$ at depths of $40-45 \mathrm{mbsf}$ in the sedimentary sequence, approaching values that are sufficiently high to generate ore-forming fluids at these shallow depths. Furthermore, the calculated thermal gradients from the active vent area are similar to paleo-geothermal gradients recorded in the oxygen isotopic composition of carbonates from the relic hydrothermal field at Site 856, which are higher than the modern measured geothermal gradient.

Carbon and oxygen isotope data of shallow carbonates at the active hydrothermal field are consistent with methane oxidation and, together with the presence of dolomite and $\mathrm{Mg}$ pore-water profiles, provide evidence for the advection of cold, oxidizing surface waters at shallow depths. From about $5 \mathrm{mbsf}$ to the base of the cored section at Site 858 and throughout the hydrothermal reservoir at Site 857, the carbonate cement and nodules with $\delta^{13} \mathrm{C}$ values between $-10 \%$ and $-25 \%$ reflect sulfate reduction and/or thermal decomposition of organic matter.

The results of this isotope study, combined with pore-water and sediment geochemistry, delineate a system of large-scale convective hydrothermal circulation through the sedimentary sequence. In addition, smaller-scale fluid advection occurs in the shallowest part of the section. The oxygen isotope data imply an altered isotopic composition for the circulating fluid indicating that the reaction rates or fluid/rock interactions must be high relative to the fluid flux rates.
\end{abstract}

\section{INTRODUCTION}

Stable isotopes have proved to be excellent recorders of the temperatures and geochemical conditions under which in-situ reactions have occurred in deep sea sediments. These studies produced fundamental insights into processes and products of mineral alteration and formation in the deep-sea environment. With the Ocean Drilling Program (ODP), greatly improved core recovery and fluid sampling continue to provide excellent material for integrated water/sediment/ rock studies and stable isotope analyses.

Stable isotope studies are particularly applicable to the scientific objectives of ODP Leg 139. This leg was designed to investigate hydrothermal processes and products at a sediment-covered seafloor spreading center (Davis, Mottl, Fisher, et al., 1992). The occurrence of carbonate cement and nodules throughout the sediments, as well as the presence of authigenic quartz and clays, have provided ideal material for stable isotope analysis. Shipboard geochemical analysis of the interstitial waters indicated that in-situ reactions were occurring as hydrothermal fluids moved through the sediments (Davis, Mottl, Fisher, et al., 1992; Ocean Drilling Program Leg 139 Scientific Drilling Party, 1992). In this study, we have analyzed the bulk chemical composition of representative sediment samples and the stable isotope compositions of carbonate cements and nodules and authigenic

\footnotetext{
${ }^{1}$ Mottl, M.J., Davis, E.E., Fisher, A.T., and Slack, J.F. (Eds.), 1994. Proc. ODP, Sci. Results, 139: College Station, TX (Ocean Drilling Program).

${ }^{2}$ Dept. of Earth Sciences, ETH-Zürich, CH-8092 Zürich, Switzerland.

${ }^{3}$ Dip. di Scienze della Terra dell'Università di Napoli, Largo S. Marcellino 10, I-80138 Napoli, Italy.

${ }^{4}$ CNRS, Centre de Géochemie de la Surface, 1 rue Blessig, F-67084 Strasbourg Cedex, France.

${ }^{5}$ Université Lille I, UFR des Sciences de la Terre, Lab. de Dynamique Sédimentaire et Structural, F-59655 Villeneuve d'Ascq Cedex, France.
}

silicates recovered at three sites: Site 856 (a former hydrothermal area), Site 857 (a "hydrothermal reservoir"), and Site 858 (an active hydrothermal discharge site). The isotopic data were used to calculate temperature gradients and are combined with bulk rock chemical data to evaluate reactions occurring along the fluid pathways. Our study, in conjunction with the shipboard results and other shore-based geochemical and isotope studies included in this volume, should provide important information that can be used to constrain fluid pathways and temperature gradients in both the active and former hydrothermal systems of the Middle Valley sedimented ridge.

\section{GEOLOGICAL SETTING}

Middle Valley is a fault-bounded, sedimented rift valley, located at the northern extremity of the Juan de Fuca Ridge, just south of the Sovanco fracture zone (e.g., Davis et al., 1987; Davis and Villinger, 1992). Because of its proximity to the North American continental margin, Middle Valley is filled with terrigenous sediments which are interbedded with pelagic to hemipelagic sediments (Goodfellow and Blaise, 1988). The thickness of the sedimentary cover is variable $(300-1500 \mathrm{~m})$ and generally increases from the margins to the center of the basin, and from south to north toward the continental margin (Davis and Lister, 1977). With only minor exceptions, the structure of the sedimentary sequences in Middle Valley indicates a relatively simple depositional history (Davis and Villinger, 1992), in which the sedimentation rate has kept pace with subsidence. Unaltered sediments of the turbidite units contain detrital and diagenetic clays, mica, quartz, amphibole, and feldspar, with variable biogenic components (Goodfellow and Blaise, 1988). The finest sediments, silty clay grading to silty sand, consist of biogenic and terrigenous components, with local concentrations of diagenetic carbonates. At the top of the sequence, the sediments are weakly indurated and altered, with abun- 


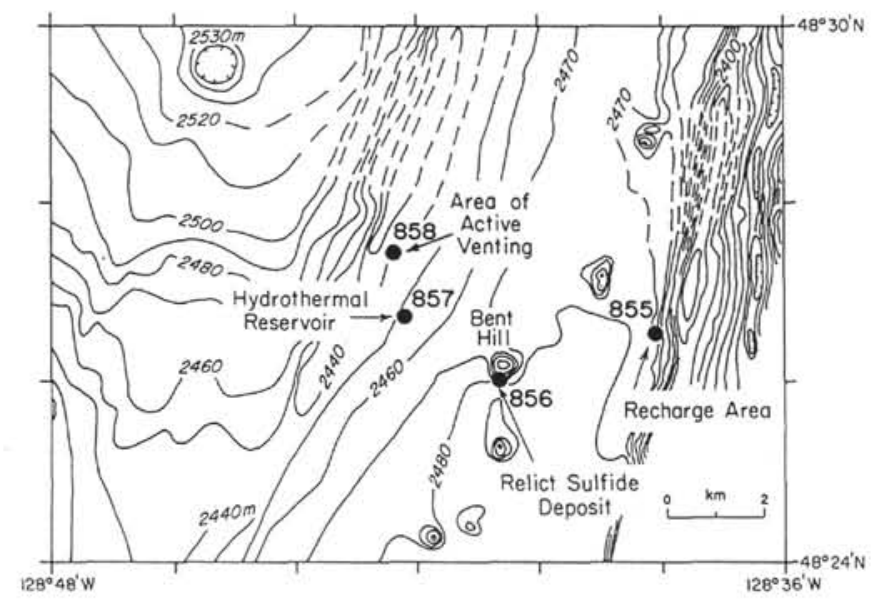

Figure 1. Regional bathymetry of Middle Valley, northern Juan de Fuca Ridge, showing locations of sites drilled during Leg 139.

dant calcite and/or dolomite nodules and concretions; they become progressively more indurated, altered, and fractured with depth.

The sediment/basement interface in Middle Valley is characterized by a gradual transition zone of intercalated sediments and basaltic sills and flows. Numerous local heat-flow anomalies occur in the valley (Davis and Villinger, 1992). A high thermal insulating capacity and low permeability of the sedimentary sequences play an important role in maintaining high fluid temperatures and facilitating hydrothermal discharge at a restricted number of vent sites (Goodfellow and Blaise, 1988).

Each of the four sites drilled in the eastern part of Middle Valley during Leg 139 (Fig. 1) is characterized by a distinct hydrologic environment. These include an area of fluid recharge at lower temperatures (Site 855), an area of active discharge characterized by high heat flow (Site 858), and a "hydrothermal reservoir" (Site 857) with high-temperature fluids well sealed underneath sediments. Site 856 is considered to be an area of former discharge where an older episode of hydrothermal activity led to extensive alteration of the sedimentary cover and to the deposition of a large body of massive sulfides (Davis, Mottl, Fisher, et al., 1992; Ocean Drilling Program Leg 139 Scientific Drilling Party, 1992). In this study, we discuss the bulk chemical and stable isotope geochemical signatures of the hydrothermally altered sedimentary sequences cored at Sites 856 and 858 and compare these with the proposed hydrothermal reservoir at Site 857.

\section{ANALYTICAL METHODS}

Carbonate mineralogy of bulk powdered samples and microsamples drilled from carbonate nodules was determined by X-ray diffraction (XRD) analysis on a computer-aided, Scintag X-ray diffractometer. Samples were run between $2^{\circ}$ and $65^{\circ} 2 \theta, 40 \mathrm{kV} / 20 \mathrm{~m} \AA$, using a $\mathrm{CuK} \alpha$ radiation, and a scan speed of $2 \% \mathrm{~min}$. It is often difficult to distinguish between ankerite and dolomite by XRD methods. In this study, dolomite was identified in samples from Sites 857 and 858 on the basis of $\mathrm{d}$-spacing and relative intensities, calibrated to an internal quartz standard. Mole percent $\mathrm{CaCO}_{3}\left(\mathrm{~N}_{\mathrm{CaCO}_{3}}\right)$ was determined from $\mathrm{d}_{104}$ using the equation of Goldsmith and Graf (1958), as modified by Lumsden (1979): $\mathrm{N}_{\mathrm{CaCo}_{3}}=333.33 \mathrm{~d}_{104}(\AA)-911.99$. Bulk mineralogies of the same sample set and microprobe chemical analyses on selected carbonate samples are reported in Buatier et al. (this volume).

Bulk chemical analyses were run on a selected number of wholerock samples and individual fragments. Prior to elemental analysis, the samples were dried at $110^{\circ} \mathrm{C}$ and melted in a mixture of lithium tetraborate; they were then introduced into a glycolated solvent. Major element analyses were performed following the method described by Besnus and Rouault (1973), using arc spectrometry and an Applied Research Laboratories quantimeter. $\mathrm{Na}$ and $\mathrm{K}$ contents were determined by emission spectrometry. Major elements are expressed in weight percentage of oxides (wt\%), and the weight loss on ignition $\left(\mathrm{LOI}\right.$, at $1000^{\circ} \mathrm{C}$ ) is in percentage for $100 \mathrm{~g}$ of dried samples and with a relative precision of $\pm 2 \%$. Trace elements were determined using an inductively coupled plasma technique (ICP-35000-ARL) (Samuel et al., 1985). The relative precision for minor elements (in parts per million, or ppm) is $\pm 10 \%$. Total carbon and sulfur contents of selected samples were measured on an infrared absorption spectrometer, with a relative precision of $\pm 5 \%$ (LECO 125). Results are given in Tables 1 and 2 .

Carbon and oxygen isotope ratios of carbonates were determined from bulk samples of soft and indurated sediments and from microsamples drilled from carbonate nodules. Organic matter was removed prior to isotope measurements by oxidation with a sodium hypochloride solution. $\mathrm{CO}_{2}$ gas for isotopic analysis was prepared from the carbonates by the reaction with phosphoric acid (McCrea, 1950). Dolomite samples were reacted for at least $72 \mathrm{hr}$ at $25^{\circ} \mathrm{C}$. Phosphoric acid correction factors of 1.01025 for calcite and 1.01190 for dolomite were applied (Sharma and Clayton, 1965).

Clay-size fractions $(<2-\mu \mathrm{m})$ were separated from bulk samples by settling in a water column. Prior to separation, each sample was dispersed in deionized water, disaggregated, decarbonated with $\mathrm{HCl} \mathrm{N} / 5$ solution, and washed several times. Clay mineral assemblages were determined by XRD analysis and are discussed in detail, together with data on clay morphologies and chemical analyses, by Buatier et al. (this volume). Authigenic quartz separates were chemically isolated from $\geq 2-\mu \mathrm{m}$ size fractions using hot, concentrated sulfuric acid. For oxygen isotope analysis, clay separates $(<2-\mu \mathrm{m}$ size fractions) were degassed at room temperature for at least $72 \mathrm{hr}$ under high vacuum and then transferred directly to nickel reaction vessels with minimal exposure to air and heated at $200^{\circ} \mathrm{C}$ for $5 \mathrm{hr}$ under vacuum. Oxygen was liberated from silicate samples by reaction with $\mathrm{ClF}_{3}$ at $600^{\circ} \mathrm{C}$ (Borthwick and Harmon, 1982) and converted to $\mathrm{CO}_{2}$ by reaction with heated carbon. For hydrogen isotope analysis, clay separates were dried at $120^{\circ} \mathrm{C}$ under vacuum overnight, then heated in a vacuum to $>1100^{\circ} \mathrm{C}$ to liberate $\mathrm{H}_{2}$ and $\mathrm{H}_{2} \mathrm{O}$. Molecular hydrogen was converted to water by reaction with copper oxide. The resulting total water was quantitatively converted to hydrogen by reaction with hot uranium.

Carbon and oxygen extraction and isotope analyses of all samples were carried out at the Department of Earth Sciences at the ETH, Zürich; hydrogen isotope analyses were conducted at the Scottish Universities Research and Reactor Centre. The isotopic ratios of all samples were determined by conventional mass spectrometric analysis and are reported as $\delta$-values in per mil $(\%)$ relative to the Pee Dee Belemnite (PDB) isotopic standard for carbonates and relative to Standard Mean Ocean Water (SMOW) for silicates. The $\delta^{18} \mathrm{O}$ values of calcite on the PDB and SMOW scales are related by the expression $\delta_{\text {SMOW }}=$ $1.03086 \delta_{\mathrm{PDB}}+30.86$ (Friedman and O'Neil, 1977). The quartz sand standard, NBS- 28 , has a value of $9.6 \%$ relative to SMOW. The overall reproducibility for carbonates is $\pm 0.2 \%$. The overall reproducibility of oxygen isotope ratios averages $\pm 0.1 \%$ for quartz and $\pm 0.2 \%$ for clays, and is $\pm 1 \%$ o for hydrogen.

Temperatures have been estimated from oxygen isotope data by applying experimentally determined fractionation factors and assuming a seawater isotopic composition of $0.0 \%$ relative to SMOW. Calcite temperatures were calculated using the calcite-water fractionation factors of O'Neil et al. (1969), as reported in Friedmann and O'Neil (1977). Dolomite temperatures were estimated using the dolomitewater fractionation factors of Matthews and Katz (1977). Quartzchlorite temperatures were calculated using the quartz-water fractionation factor $\left(200^{\circ} \mathrm{C}\right.$ to $\left.500^{\circ} \mathrm{C}\right)$ of Clayton et al. (1972), as reported in Friedmann and O'Neil (1977), and the preliminary experimental data of Cole (1985) for the oxygen isotope fractionation between chlorite and water. 
Table 1. Chemical composition of bulk sediments from Sites 856 and 858: major elements (wt \%).

\begin{tabular}{|c|c|c|c|c|c|c|c|c|c|c|c|c|c|}
\hline Sample $(\mathrm{cm})$ & $\begin{array}{l}\text { Depth } \\
\text { (mbsf) }\end{array}$ & $\mathrm{SiO}_{2}$ & $\mathrm{Al}_{2} \mathrm{O}_{3}$ & $\mathrm{MgO}$ & $\mathrm{CaO}$ & $\mathrm{Fe}_{2} \mathrm{O}_{3}$ & $\mathrm{Mn}_{3} \mathrm{O}_{4}$ & $\mathrm{TiO}_{2}$ & $\mathrm{Na}_{2} \mathrm{O}$ & $\mathrm{K}_{2} \mathrm{O}$ & $\mathrm{P}_{2} \mathrm{O}_{5}$ & LOI & Total \\
\hline \multicolumn{14}{|l|}{$139-856 \mathrm{~A}-$} \\
\hline $1 \mathrm{H}-1,48-51$ & 2.32 & 48.7 & 14.3 & 3.31 & 5.6 & 6.8 & 0.104 & 0.69 & 3.99 & 2.55 & 0.14 & 10.59 & 96.77 \\
\hline $4 \mathrm{H}-1,36-40$ & 22.06 & 56.8 & 16.6 & 3.91 & 3.1 & 7.6 & 0.109 & 0.85 & 3.44 & 2.69 & 0.17 & 5.64 & 100.91 \\
\hline $6 \mathrm{H}-7,20-24$ & 49.90 & 62.0 & 14.0 & 3.03 & 3.5 & 5.4 & 0.088 & 0.81 & 3.61 & 1.75 & 0.17 & 3.69 & 98.05 \\
\hline $7 \mathrm{H}-7,49-52$ & 59.69 & 32.4 & 10.9 & 9.09 & 16.7 & 7.2 & 0.824 & 0.58 & 1.19 & 0.37 & 0.24 & 18.95 & 98.44 \\
\hline $10 X-2,81-83$ & 81.01 & 63.4 & 14.7 & 2.97 & 2.2 & 5.3 & 0.072 & 0.76 & 3.91 & 1.67 & 0.18 & 2.77 & 97.93 \\
\hline $13 X-2,37-41$ & 107.17 & 58.0 & 14.9 & 6.16 & 0.6 & 6.7 & 0.121 & 0.84 & 3.46 & 2.08 & 0.16 & 4.81 & 97.83 \\
\hline \multicolumn{14}{|l|}{ 139-856B- } \\
\hline $2 \mathrm{H}-7,32-36$ & 11.12 & 56.7 & 16.2 & 6.23 & 0.5 & 6.8 & 0.106 & 0.78 & 2.74 & 3.51 & 0.14 & 3.56 & 97.27 \\
\hline $5 \mathrm{H}-4,110-115$ & 35.90 & 66.0 & 7.5 & 14.50 & 0.6 & 3.3 & 0.126 & 0.39 & 0.44 & 0.09 & 0.05 & 5.21 & 98.21 \\
\hline $9 \mathrm{H}-2,74-77$ & 64.54 & 64.6 & 13.8 & 5.00 & 0.3 & 4.8 & 0.130 & 0.81 & 3.40 & 1.14 & 0.15 & 4.62 & 98.75 \\
\hline $12 X-2,114-118$ & 84.24 & 61.5 & 14.3 & 7.04 & 0.3 & 5.1 & 0.310 & 0.70 & 3.86 & 0.74 & 0.14 & 4.83 & 98.82 \\
\hline $15 X-4,31-33$ & 115.21 & 64.5 & 11.6 & 2.56 & 0.3 & 13.1 & 0.181 & 0.58 & 0.44 & 1.55 & 0.22 & 4.05 & 99.08 \\
\hline \multicolumn{14}{|l|}{$139-858 \mathrm{~A}-$} \\
\hline $2 \mathrm{H}-3,36-40$ & 5.76 & 54.2 & 13.8 & 3.34 & 4.9 & 6.8 & 0.107 & 0.75 & 3.71 & 2.47 & 0.15 & 8.48 & 98.71 \\
\hline $3 \mathrm{H}-1,58-60$ & 12.48 & 56.9 & 15.9 & 3.16 & 1.8 & 7.5 & 0.144 & 0.76 & 3.58 & 2.75 & 0.15 & 7.66 & 100.30 \\
\hline $5 \mathrm{H}-4,27-30$ & 35.67 & 58.0 & 14.9 & 3.02 & 2.7 & 6.0 & 0.089 & 0.79 & 2.43 & 4.15 & 0.17 & 5.19 & 97.44 \\
\hline $11 \mathrm{X}-\mathrm{CC}, 12-14$ & 73.59 & 59.9 & 12.6 & 2.57 & 5.7 & 6.8 & 0.097 & 0.70 & 2.53 & 2.85 & 0.12 & 4.10 & 97.97 \\
\hline $12 \mathrm{X}-\mathrm{CC}, 14-15$ & 81.94 & 10.8 & 3.9 & 2.37 & 41.6 & 2.9 & 0.519 & 0.23 & 0.05 & 0.05 & 0.14 & 34.13 & 96.69 \\
\hline $18 X-2,132-134$ & 142.42 & 46.5 & 14.5 & 6.39 & 5.1 & 7.0 & 0.128 & 0.74 & 2.43 & 1.74 & 0.16 & 5.74 & 90.43 \\
\hline $27 \mathrm{X}-1,24-26$ & 226.97 & 56.2 & 14.7 & 4.05 & 3.2 & 6.2 & 0.116 & 0.79 & 4.94 & 0.63 & 0.16 & 3.83 & 94.82 \\
\hline $31 X-2,3-5$ & 266.17 & 52.1 & 16.7 & 6.21 & 1.1 & 7.8 & 0.126 & 0.85 & 4.01 & 1.57 & 0.17 & 4.97 & 95.61 \\
\hline \multicolumn{14}{|l|}{ 139-858B- } \\
\hline $2 \mathrm{H}-1,97-99$ & 8.17 & 48.6 & 15.3 & 13.50 & 0.9 & 6.9 & 0.113 & 0.71 & 2.79 & 2.43 & 0.30 & 8.08 & 99.62 \\
\hline $2 \mathrm{H}-2,45-47$ & 9.15 & 49.9 & 15.3 & 6.81 & 1.6 & 7.5 & 0.094 & 0.73 & 3.34 & 2.99 & 0.18 & 7.72 & 96.16 \\
\hline $2 \mathrm{H}-3,75-77$ & 10.95 & 17.9 & 2.3 & 8.92 & 0.4 & 40.8 & 0.099 & 0.12 & 1.37 & 0.09 & 0.25 & 25.44 & 97.69 \\
\hline $2 \mathrm{H}-4,72-74$ & 12.42 & 10.8 & 4.8 & 7.39 & 25.1 & 7.8 & 0.103 & 0.28 & 0.47 & 0.07 & 0.11 & 9.75 & 66.67 \\
\hline $2 \mathrm{H}-5,113-115$ & 14.33 & 52.2 & 14.0 & 9.51 & 3.8 & 7.2 & 0.156 & 0.66 & 2.21 & 1.07 & 0.15 & 7.17 & 98.13 \\
\hline $2 \mathrm{H}-6,89-91$ & 15.59 & 58.5 & 13.2 & 7.82 & 0.6 & 6.9 & 0.112 & 0.71 & 2.05 & 1.66 & 0.13 & 6.19 & 97.87 \\
\hline $5 \mathrm{H}-2,69-73$ & 26.09 & 50.0 & 4.6 & 29.40 & 1.4 & 3.2 & 0.148 & 0.27 & 1.11 & 0.13 & 0.11 & 7.26 & 97.63 \\
\hline $5 \mathrm{H}-3,58-62$ & 27.48 & 56.4 & 15.3 & 3.81 & 3.2 & 6.1 & 0.142 & 0.81 & 3.78 & 2.05 & 0.17 & 6.64 & 98.40 \\
\hline $5 \mathrm{H}-4,55-59$ & 28.95 & 46.3 & 6.4 & 31.00 & 1.0 & 4.0 & 0.145 & 0.30 & 0.83 & 0.12 & 0.05 & 8.27 & 98.41 \\
\hline $6 \mathrm{H}-1,51-53$ & 32.01 & 71.5 & 7.1 & 9.30 & 0.3 & 5.3 & 0.086 & 0.36 & 0.34 & 0.10 & 0.05 & 4.57 & 99.01 \\
\hline
\end{tabular}

Table 2. Chemical composition of bulk sediments from Sites 856 and 858: trace elements (ppm), C, and $\mathrm{S}(\mathrm{wt} \%)$.

\begin{tabular}{|c|c|c|c|c|c|c|c|c|c|c|c|c|}
\hline Sample $(\mathrm{cm})$ & $\begin{array}{l}\text { Depth } \\
\text { (mbsf) }\end{array}$ & $\mathrm{Sr}$ & $\mathrm{Ba}$ & V & $\mathrm{Ni}$ & $\mathrm{Co}$ & $\mathrm{Cu}$ & $\mathrm{Cr}$ & $\mathrm{Zn}$ & $\mathrm{Zr}$ & $\mathrm{C} \%$ & $\mathrm{~S} \%$ \\
\hline \multicolumn{13}{|l|}{$139-856 \mathrm{~A}-$} \\
\hline $1 \mathrm{H}-1,48-51$ & 2.32 & 349 & 1728 & 146 & 78 & 25 & 50 & 92 & 80 & 118 & & \\
\hline $4 \mathrm{H}-1,36-40$ & 22.06 & 255 & 584 & 146 & 55 & 19 & 38 & 94 & 82 & 127 & & \\
\hline $6 \mathrm{H}-7,20-24$ & 49.90 & 272 & 596 & 131 & 56 & 23 & 29 & 114 & 56 & 167 & & \\
\hline $7 \mathrm{H}-7,49-52$ & 59.69 & 162 & 210 & 117 & 62 & 20 & 46 & 84 & 114 & 78 & 3.98 & 0.19 \\
\hline $10 X-2,81-83$ & 81.01 & 348 & 520 & 134 & 42 & 19 & 27 & 104 & 66 & 153 & & \\
\hline $13 X-2,37-41$ & 107.17 & 135 & 475 & 157 & 72 & 21 & 31 & 91 & 108 & 141 & 0.22 & 0.31 \\
\hline \multicolumn{13}{|l|}{ 139-856B- } \\
\hline $2 \mathrm{H}-7,32-36$ & 11.12 & 98 & 716 & 163 & 66 & 18 & 21 & 95 & 104 & 109 & & \\
\hline $5 \mathrm{H}-4,110-115$ & 35.90 & 19 & 22 & 76 & 28 & 13 & 11 & 44 & 54 & 62 & 0.39 & 0.26 \\
\hline $9 \mathrm{H}-2,74-77$ & 64.54 & 56 & 126 & 124 & 100 & 24 & 20 & 101 & 58 & 210 & 0.12 & 1.33 \\
\hline $12 X-2,114-118$ & 84.24 & 49 & 66 & 117 & 37 & 9 & 12 & 60 & 189 & 221 & 1.31 & 1.50 \\
\hline $15 X-4,31-33$ & 115.21 & 14 & 313 & 94 & 33 & 26 & 2352 & 76 & 80 & 113 & & \\
\hline \multicolumn{13}{|l|}{ 139-858A- } \\
\hline $2 \mathrm{H}-3,36-40$ & 5.76 & 293 & 639 & 150 & 52 & 22 & 49 & 97 & 76 & 122 & 1.27 & 0.44 \\
\hline $3 \mathrm{H}-1,58-60$ & 12.48 & 220 & 598 & 157 & 50 & 21 & 54 & 101 & 115 & 125 & 0.75 & 1.78 \\
\hline $5 \mathrm{H}-4,27-30$ & 35.67 & 166 & 720 & 136 & 50 & 20 & 31 & 96 & 76 & 154 & 0.68 & 0.22 \\
\hline $11 X-C C, 12-14$ & 73.59 & 148 & 638 & 110 & 53 & 12 & 23 & 86 & 53 & 149 & & \\
\hline $12 \mathrm{X}-\mathrm{CC}, 14-15$ & 81.94 & 244 & 91 & 34 & 27 & 5 & 9 & 26 & 25 & 28 & 10.00 & 0.12 \\
\hline $18 X-2,132-134$ & 142.42 & 187 & 266 & 141 & 64 & 23 & 32 & 94 & 91 & 99 & 0.34 & 2.96 \\
\hline $27 X-1,24-26$ & 226.97 & 157 & 143 & 129 & 40 & 17 & 45 & 88 & 142 & 124 & 0.22 & 1.74 \\
\hline $31 \times-2,3-5$ & 266.17 & 97 & 227 & 161 & 243 & 26 & 33 & 93 & 102 & 105 & 0.29 & 1.22 \\
\hline \multicolumn{13}{|l|}{ 139-858B- } \\
\hline $2 \mathrm{H}-1,97-99$ & 8.17 & 99 & 587 & 138 & 57 & 26 & 55 & 78 & 108 & 99 & 0.32 & 1.27 \\
\hline $2 \mathrm{H}-2,45-47$ & 9.15 & 163 & 680 & 151 & 53 & 25 & 59 & 85 & 117 & 106 & 0.58 & 2.06 \\
\hline $2 \mathrm{H}-3,75-77$ & 10.95 & 22 & 12 & 83 & 35 & 22 & 3453 & 37 & 14635 & 18 & 0.47 & $27.5^{\mathrm{a}}$ \\
\hline $2 \mathrm{H}-4,72-74$ & 12.42 & 937 & 20 & 49 & 27 & 8 & 83 & 36 & 265 & 47 & 0.24 & $18.1^{\mathrm{a}}$ \\
\hline $2 \mathrm{H}-5,113-115$ & 14.33 & 98 & 281 & 129 & 70 & 22 & 131 & 82 & 294 & 104 & 0.71 & 1.33 \\
\hline $2 \mathrm{H}-6,89-91$ & 15.59 & 65 & 253 & 138 & 51 & 21 & 35 & 79 & 149 & 94 & 0.25 & 0.58 \\
\hline $5 \mathrm{H}-2,69-73$ & 26.09 & 47 & 11 & 46 & 32 & 14 & 11 & 32 & 55 & 45 & & \\
\hline $5 \mathrm{H}-3,58-62$ & 27.48 & 291 & 882 & 134 & 41 & 15 & 13 & 88 & 83 & 136 & 0.17 & 0.92 \\
\hline $5 \mathrm{H}-4,55-59$ & 28.95 & 33 & 15 & 61 & 32 & 11 & 7 & 41 & 84 & 44 & & \\
\hline $6 \mathrm{H}-1,51-53$ & 32.01 & 11 & 25 & 59 & 34 & 12 & 11 & 41 & 76 & 49 & 0.13 & 0.60 \\
\hline
\end{tabular}

${ }^{\text {a }} \mathrm{S} \%$ contents given with a precision of about $\pm 2 \%$. 


\section{RESULTS AND DISCUSSION}

\section{Former Hydrothermal Discharge (Site 856)}

Site 856 is situated around a small circular hill in the eastern part of Middle Valley, about $3 \mathrm{~km}$ west of a fault scarp which forms the eastern topographic boundary of the valley (Fig. 1). The hill is made up of uplifted sediments, overlying a bright seismic reflector which is thought to be sills or a small laccolithic intrusion (Davis, Mottl, Fisher, et al., 1992; Ocean Drilling Program Leg 139 Scientific Drilling Party, 1992). No heat flow anomaly is presently associated with the hill, nor is there active venting directly at Site 856 . However, a small hydrothermal field occurs about $300 \mathrm{~m}$ to the south of the southern flank of the hill where clear water is currently discharging at $264^{\circ} \mathrm{C}$. A mound of massive sulfides outcrops directly south of the hill and is the site of six holes, Holes $856 \mathrm{C}$ through $856 \mathrm{H}$. Virtually pure massive sulfide rock was recovered from each of these holes. Shipboard studies showed that the massive sulfide deposit is more than 60 $\mathrm{m}$ wide and $95 \mathrm{~m}$ thick and clearly represents a major accumulation of metal sulfide precipitated during former hydrothermal discharge (Ocean Drilling Program Leg 139 Scientific Drilling Party, 1992). Holes $856 \mathrm{~A}$ and $856 \mathrm{~B}$ were drilled directly into the hill at Site 856; Hole $856 \mathrm{~A}$ is at the center and Hole $856 \mathrm{~B}$ is on the flank of the hill. Both holes contain variably altered sediments but no massive sulfide intervals. These two holes may be the more distal portion of the former, possibly asymmetric, vent field which produced the massive sulfides recovered in the other holes. In this study, stable isotope ratios of carbonates from Hole $856 \mathrm{~A}$ and bulk rock geochemical data from Holes $856 \mathrm{~A}$ and $856 \mathrm{~B}$ are used to compare the alteration history of this mature, relic high-temperature discharge site with the alteration history recorded in the sediments at the active vent system at Site 858 , approximately $3 \mathrm{~km}$ to the northeast (see Fig. 1).

The sediments from the northernmost hole, Hole 856A, contain a relatively complete record of hemipelagic and turbiditic sedimentation in which hydrothermal activity produced an alteration zone dominated by carbonate nodules, concretions, and fracture fillings. A greater degree of hydrothermal alteration in the sediments from Hole $856 \mathrm{~B}$ is reflected by low carbonate contents, enrichment in pyrite, albitization of feldspar and replacement by clays. These sediments are moderately to intensively indurated, brecciated and fractured. The bulk mineralogical and geochemical compositions of the sediments reflect the interlayering and mixed nature of detrital and hydrothermal phases (see Buatier et al., this volume). The ratio $\mathrm{Al} /(\mathrm{Al}+\mathrm{Fe}+$ $\mathrm{Mn}$ ) is an index of detrital clay component; generally a ratio greater than 0.4 is considered to indicate a detrital source in marine sediments (Boström and Peterson, 1969; Boström, 1973; 1983). The majority of the samples studied from Site 856 have values at or above 0.4 for this ratio. The dominant detrital continental contribution in Holes $856 \mathrm{~A}$ and $856 \mathrm{~B}$ as well as a lack of basaltic contribution is well defined in a plot of $\mathrm{Fe} / \mathrm{Ti}$ vs. $\mathrm{Al} /(\mathrm{Al}+\mathrm{Fe}+\mathrm{Mn})$, shown in Fig. 2 .

In Hole 856A, carbonate concretions occur in interbedded hemipelagic and turbiditic sediments that become increasingly more indurated with depth. The concretions appear at approximately $17 \mathrm{mbsf}$ (Davis, Mottl, Fisher, et al., 1992) and are more abundant in the turbiditic beds than in the argillaceous intervals. The presence of carbonate nodules can be correlated with a decrease in the preservation of calcareous biogenic components. The major proportion of the carbonate in both the sediment and the concretions consists of bright redorange luminescing calcite. Recrystallization and replacement microtextures and carbonate chemistries indicate that this type of calcite is authigenic in origin (see Buatier et al., this volume). Foraminifers are partially preserved to depths of $50 \mathrm{mbsf}$, but cathode luminescence studies show that these are progressively recrystallized and are filled with the red-orange, authigenic calcite. X-ray diffraction analyses indicate high- $\mathrm{Mg}$ calcite (up to $7 \mathrm{~mole} \% \mathrm{MgCO}_{3}$ ) in one sample at $17 \mathrm{mbsf}$ and two samples at about $41 \mathrm{mbsf}$, whereas the other samples of carbonate cements and nodules are composed of low-Mg calcite (see Table 3). Electron microprobe analyses show that the authigenic carbonate is enriched in Mn (Table 5 in Buatier et al., this volume).

With the exception of one surface sample at $0.48 \mathrm{mbsf}$ (Sample $139-856 \mathrm{~A}-1 \mathrm{H}-1,48-51 \mathrm{~cm}$ ) which has typical marine $\delta^{18} \mathrm{O}$ and $\delta^{13} \mathrm{C}$ values, i.e., near zero per mil relative to $\mathrm{PDB}$, all of the calcite cements and calcite nodules from Hole $856 \mathrm{~A}$ are depleted in both ${ }^{13} \mathrm{C}$ and ${ }^{18} \mathrm{O}$ relative to normal marine carbonates (Table 3; Figs. 3A and 3B). Values of $\delta^{13} \mathrm{C}$ range from approximately $-22 \%$ to $-5 \%$ (PDB) and can vary by as much as $7 \%$ over a $1-\mathrm{m}$ depth interval. Low $\delta^{13} \mathrm{C}$ values are typical of carbonate nodules in the sediments of Middle Valley (e.g., $\mathrm{Al}$-Aasm and Blaise, 1991). The depletion in ${ }^{13} \mathrm{C}$ reflects the incorporation of carbonate ions derived from organic matter either (1) through sulfate reduction, in which organic matter is oxidized by bacterial and/or thermochemical processes to produce bicarbonate $\left(\mathrm{HCO}_{3}\right)$, hydrogen sulfide $\left(\mathrm{H}_{2} \mathrm{~S}\right)$, and/or ammonia $\left(\mathrm{NH}_{4}\right)$ (e.g., Machel, 1987; Raiswell, 1987), or (2) from thermal decomposition of organic matter in the absence of sulfate at high temperatures.

The $\delta^{18} \mathrm{O}$ values of the calcite cements and nodules scatter about a mean of approximately $-13 \%$ (Fig. 3B; Table 3 ), with a maximum depletion to a value of $-17 \%$ (PDB) at $58 \mathrm{mbsf}$ in Sample 139-856 A$7 \mathrm{H}-\mathrm{CC}, 38-42 \mathrm{~cm}$. Detailed profiles measured across two nodules (Samples 139-856A-6H-4, 73-76 cm at $45.93 \mathrm{mbsf}$, and 139-856A$12 \mathrm{X}-5,14-17 \mathrm{~cm}$ at $95.84 \mathrm{mbsf}$ ) show systematic variations of increasing $\delta^{13} \mathrm{C}$ and decreasing $\delta^{18} \mathrm{O}$ values toward the rims, indicating changes in temperature and/or changes in the isotopic composition of the precipitating fluid as the nodules grew. A change in conditions of comparable magnitude is particularly evident by the distinct range in $\delta^{13} \mathrm{C}$ and $\delta^{18} \mathrm{O}$ values between 40 and $60 \mathrm{mbsf}$ (Figs. $3 \mathrm{~A}$ and $3 \mathrm{~B}$ ). At this depth interval carbon becomes more depleted in ${ }^{13} \mathrm{C}$, whereas oxygen becomes enriched in ${ }^{18} \mathrm{O}$ relative to the compositions in both the overlying and the underlying sediments.

The strong ${ }^{18} \mathrm{O}$ depletions in the carbonates reflect (1) precipitation at elevated temperatures either in the presence of marine water or a more ${ }^{18} \mathrm{O}$-enriched fluid, or (2) precipitation at low temperatures from ${ }^{18} \mathrm{O}$-depleted fluids. Low temperatures of formation are unlikely in this hydrothermal environment and are inconsistent with the coexisting clay mineralogies, which show a change from smectite- to chlorite-dominant assemblages indicative of increasing temperatures (Buatier et al., this volume; see also subsequent discussion of Site $858)$. Thus, it is more likely that the carbonate was precipitated at elevated temperatures from hydrothermal fluids either dominated by seawater or slightly enriched in ${ }^{18} \mathrm{O}$. In the absence of direct oxygen isotope data from the hydrothermal fluids, estimates of precipitation temperatures can be made by assuming equilibrium with seawater (i.e., 0\% SMOW), as shown in Fig. 3C. Obviously, this is a first approximation and only yields minimum temperatures. The equilibrium temperatures would be greater if the fluid were enriched in ${ }^{18} \mathrm{O}$ relative to seawater.

Assuming equilibrium with seawater, the oxygen isotope profiles suggest that carbonate cement precipitation and growth of the carbonate concretions occurred progressively as temperatures increased, reaching up to approximately $140^{\circ} \mathrm{C}$ at $60 \mathrm{mbsf}$ (Table 3). These estimates suggest that the temperature gradient during the active hydrothermal event was distinctly higher than the present temperature gradient of $0.50^{\circ} \mathrm{C} / \mathrm{m}$, estimated from in-situ measurements in Hole $856 \mathrm{~A}$ (Fig. 3) (Davis, Mottl, Fisher, et al., 1992). The modern gradient at the adjacent hole, Hole $856 \mathrm{~B}$, is 2.5 times higher $\left(1.27^{\circ} \mathrm{C} / \mathrm{m}\right)$, and the isotope temperatures of many of the nodules at or below 40-60 mbsf appear to reflect precipitation at temperatures along this higher gradient (Fig. 3C). Above the zone at $40-60 \mathrm{mbsf}$, the oxygen isotope ratios of the cements and nodules reflect an even higher paleo-temperature gradient and/or fluid influx and deposition from an isotopically different hydrothermal fluid.

The $\mathrm{C}$ - and $\mathrm{O}$-isotope data indicates a lack of isotopic equilibrium through the sedimentary sequence and may record superimposed episodes of hydrothermal activity. Interestingly, the variation in isotopic ratios of the carbonates between 40 and $60 \mathrm{mbsf}$ occurs at the 
depth at which changes in pore fluid and sediment chemistries were observed in Holes 856A and 856B (Davis, Mottl, Fisher, et al., 1992). These include increases in alkalinity and $\mathrm{NH}_{4}$ and decreases in sulfate and $\mathrm{Si}$ in the pore fluids compared with those in the overlying and underlying sediments. Shipboard chemical analyses of total C, H, N, and $\mathrm{S}$ in the sediments showed a general decrease in $\mathrm{C} / \mathrm{H}$ and $\mathrm{C} / \mathrm{N}$, with an increase in both sulfur and pyrite content below 40 mbsf. Although the present-day pore-fluid chemistry may not completely represent that during the main hydrothermal event that produced the massive sulfides, a decrease in sulfate together with the increases in alkalinity, ammonium, and silica are consistent with processes of degradation of organic matter associated with sulfate reduction and dissolution of biogenic silica.

Two possible causes for the distinct changes in pore fluid and sediment chemistries between 40 and 60 mbsf have been put forward by the Leg 139 shipboard scientists (Davis, Mottl, Fisher, et al., 1992). One is that heat from the intrusion of a sill, drilled at $62 \mathrm{mbsf}$ in Hole $856 \mathrm{~B}$, caused diagenetic production of ammonium and promoted silica dissolution and calcium sulfate precipitation at varying lateral distances. The second possible cause is that lateral convective flow occurs at this depth level. The carbon and oxygen isotope profiles at $40-60 \mathrm{mbsf}$ at Hole $856 \mathrm{~A}$, as well as the inferred higher equilibrium temperatures above this zone, are consistent with either explanation. Heat from the intrusion would have induced free convective circulation of heated marine waters and may have promoted carbonate deposition at higher temperatures in the sediments above the sill. The sill itself could have acted as an impermeable boundary to fluid penetration below this zone, resulting in less effective convection and heat transfer below the sill.

\section{Hydrothermal Reservoir (Site 857)}

Site 857 is located about $5 \mathrm{~km}$ west of the fault scarp that bounds Middle Valley on the east and is $2 \mathrm{~km}$ south of an active vent field at Site 858 (Fig. 1). Four holes through the thick sedimentary sequence were drilled with the intention of penetrating into the "hydrologic basement" away from areas of discharge or recharge. This site is characterized by high heat flow and is considered to contain a regional hydrothermal reservoir beneath the thick sediment fill (Davis, Mottl, Fisher, et al., 1992), where high-temperature fluids interact with the upper igneous crust and supply the fluids to seafloor vents several km away (Ocean Drilling Program Leg 139 Scientific Drilling Party, 1992). As in the other drill sites in the Middle Valley, the sedimentary cover consists primarily of interbedded turbidites and hemipelagic sediments and becomes progressively indurated and hydrothermally altered with increasing depth.

Authigenic carbonate occurs predominantly as carbonate cement and carbonate nodules between 46 and $461 \mathrm{mbsf}$, whereby the nodules become less common as induration increases. Nonstoichiometric, $\mathrm{Ca}$ rich dolomite has been identified at depths between 85 and 102 mbsf in Hole $857 \mathrm{~A}$ and between 76 and 95 mbsf in Hole 857C. Directly below this dolomite zone, the calcite nodules are $\mathrm{Mg}$-rich with approximately 6 mole $\% \mathrm{MgCO}_{3}$ (Table 4). No significant amount of carbonate was detected by XRD analysis of bulk sediment samples from between 145 and 230 mbsf (see Table 3 in Buatier et al., this volume). Other major authigenic phases include disseminated and nodular pyrite, and chlorite. Bulk-rock XRD determinations indicate a relative increase in the amount of chlorite at depths below approximately $145 \mathrm{mbsf}$ (e.g., Buatier et al., this volume; Davis, Mottl, Fisher, et al., 1992).

The stable isotope ratios of carbonates from Holes $857 \mathrm{~A}$ and $857 \mathrm{C}$ provide a record of authigenesis associated with high heat flow and fluid-rock interaction in a convective hydrothermal system. With the exception of one sample at a shallow depth (Sample 139-857A-1H-7, $27-31 \mathrm{~cm} ; 11 \mathrm{mbsf}$ ) that has typical marine $\delta^{13} \mathrm{C}$ and $\delta^{18} \mathrm{O}$ values, all of the carbonate samples are depleted in ${ }^{13} \mathrm{C}$ relative to normal marine carbonates (Table 4; Fig. 4A). $\delta^{13} \mathrm{C}$ values are variable and range from approximately $-18.6 \%$ to $-9.9 \%$ ( $\mathrm{PDB}$ ). In general, the carbonates

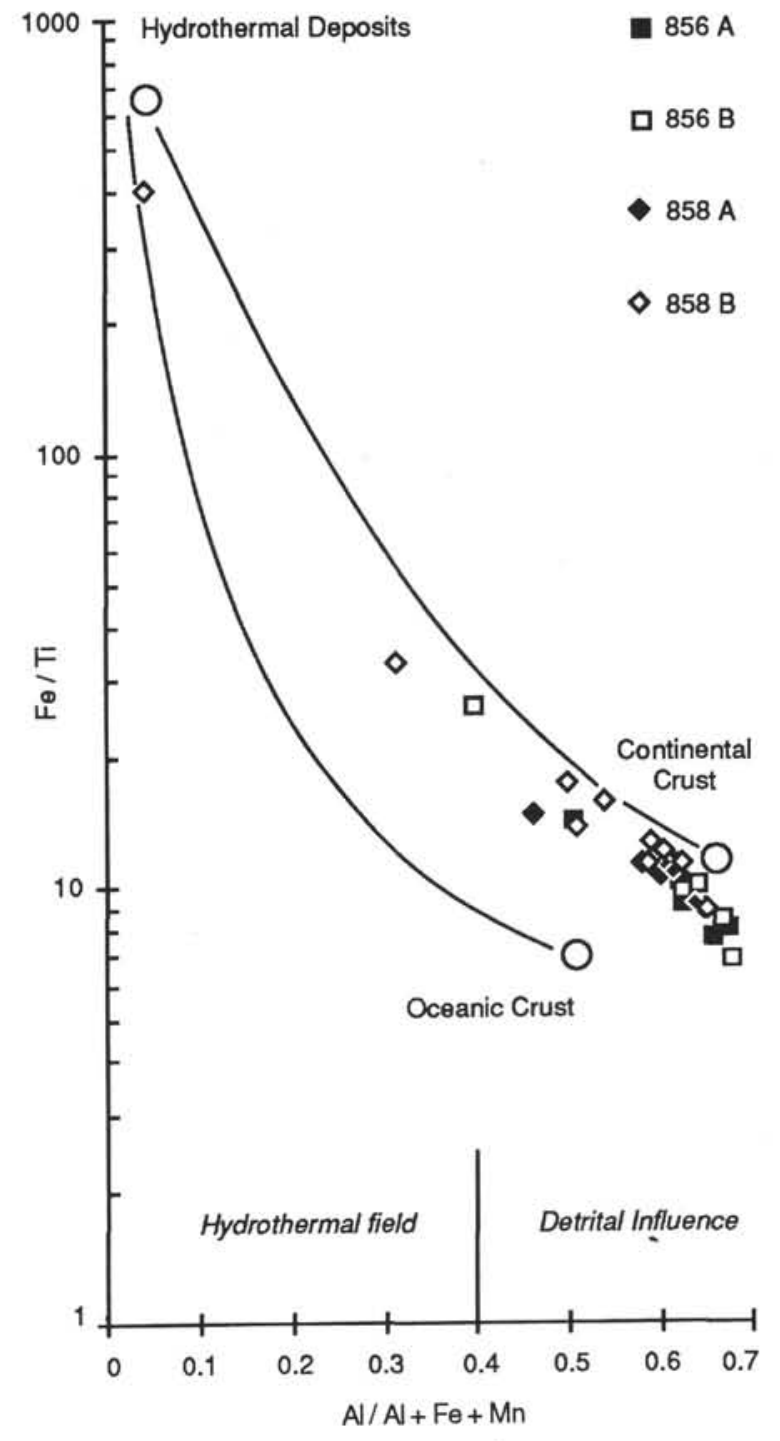

Figure 2. Relationship between $\mathrm{Al} / \mathrm{Al}+\mathrm{Fe}+\mathrm{Mn}$ and $\mathrm{Fe} / \mathrm{Ti}$ in sediments from Holes 856A, 856B, 858A, and 858B (after Boström, 1970; 1973; 1983). Plot includes ideal mixing curves from hydrothermal deposits to the mean values of continental crust and oceanic crust or basalts.

from Hole $857 \mathrm{~A}$ and the top $150 \mathrm{~m}$ of Hole $857 \mathrm{C}$ have more negative $\delta^{13} \mathrm{C}$ values than the carbonates in Hole $857 \mathrm{C}$ that occur below 268 mbsf. There are no significant differences between $\delta^{13} \mathrm{C}$ values of the dolomite cements and those of the dolomite nodules. In addition, $\delta^{13} \mathrm{C}$ values of dolomite-bearing samples are similar to those of calcitebearing samples.

As at Site 856 , the depletion in ${ }^{13} \mathrm{C}$ relative to marine carbonates reflects the oxidation of organic matter either by bacterial and/or thermochemical sulfate reduction, or by thermal cracking of hydrocarbons. Although it is difficult to distinguish these processes in hydrothermal systems, thermochemical sulfate reduction or thermal decomposition of organic matter in the absence of sulfate generally occur at higher temperatures $\left(>100^{\circ}-140^{\circ} \mathrm{C}\right)$. Bacterial oxidation of organic matter has been assumed to occur at temperatures below about $85^{\circ} \mathrm{C}(\mathrm{e} . \mathrm{g}$., Machel, 1987), but may occur at temperatures up to $110^{\circ} \mathrm{C}$ in sediments in deep-sea hydrothermal vents (Jørgensen et al., 1992). This process may be operative in the upper part of the sedimentary pile at Site 857, where sediment temperatures below approximately $100^{\circ} \mathrm{C}$ are implied from the temperature gradients estimated by in-situ measurements (Davis, Mottl, Fisher, et al., 1992; see also Fig. 4C). Sulfate reduction 


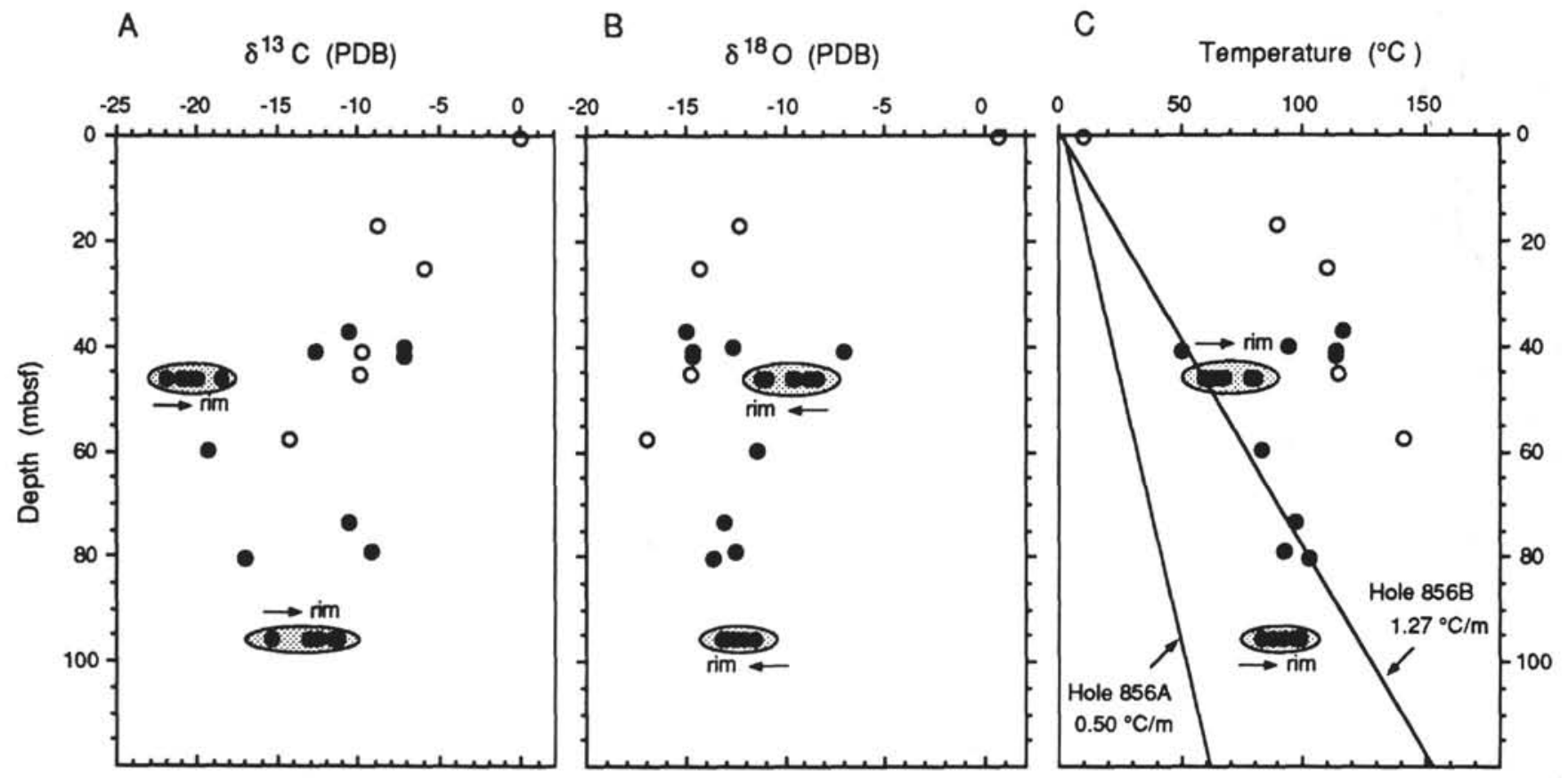

Figure 3. Carbon (A) and oxygen (B) isotope ratios (\%o relative to PDB) of calcite cements (open circles) and calcite nodules (filled circles) as a function of depth from samples of the former discharge region at Hole 856A. The shaded regions represent profiles across single nodules, with arrows showing the direction toward the rim (see Table 3). C. Calculated temperatures of carbonate formation assuming a seawater isotopic composition of $0.0 \%$ SMOW. The straight lines show the present-day thermal gradient estimated from in-situ temperature measurements at Holes 856A and 856B (Davis, Mottl, Fisher, et al., 1992).

Table 3. Carbonate compositions, stable isotope data, and temperature estimates for samples from the former discharge region at Site 856.

\begin{tabular}{|c|c|c|c|c|c|c|c|c|}
\hline $\begin{array}{l}\text { Core, section, } \\
\text { interval }(\mathrm{cm})\end{array}$ & $\begin{array}{l}\text { Depth } \\
\text { (mbsf) }\end{array}$ & $\begin{array}{c}\text { General sample } \\
\text { description }\end{array}$ & $\begin{array}{l}\text { Carbonate } \\
\text { mineralogy }\end{array}$ & $\begin{array}{c}\mathrm{CaCO}_{3} \\
(\text { mole \%) }\end{array}$ & $\begin{array}{c}\delta^{13} \mathrm{C} \%_{0} \\
(\mathrm{PDB})\end{array}$ & $\begin{array}{c}\delta^{18} \mathrm{O} \% 0 \\
\text { (PDB) }\end{array}$ & $\begin{array}{l}\delta^{18} \mathrm{O} \% \\
(\mathrm{SMOW})\end{array}$ & $\begin{array}{c}\text { Temperature } \\
\left({ }^{\circ} \mathrm{C}\right)^{\mathrm{a}}\end{array}$ \\
\hline \multicolumn{9}{|l|}{$139-856 \mathrm{~A}-$} \\
\hline $1 \mathrm{H}-1,48-51$ & 0.48 & Bulk foraminifer sand & Calcite & & -0.12 & 0.93 & 31.82 & 10 \\
\hline $3 \mathrm{H}-4,42-43$ & 17.12 & Mud & Calcite & 92.7 & -8.79 & -12.32 & 18.16 & 90 \\
\hline $4 \mathrm{H}-3,39-43$ & 25.09 & Mud & Calcite & 97.8 & -5.89 & -14.33 & 16.09 & 110 \\
\hline $5 \mathrm{H}-5,100-103$ & 37.08 & Soft nodule & Calcite & 99.0 & -10.63 & -14.96 & 15.44 & 116 \\
\hline $5 \mathrm{H}-7,123-125$ & 40.31 & Soft nodule & Calcite & 98.4 & -7.16 & -12.68 & 17.79 & 94 \\
\hline $6 \mathrm{H}-1,17-21$ & 40.87 & Mud & Calcite & 98.2 & -9.80 & -14.63 & 15.78 & 113 \\
\hline $6 \mathrm{H}-1,17-21$ & 40.87 & Nodule & Calcite & 94.9 & -12.61 & -6.99 & 23.65 & 50 \\
\hline $6 \mathrm{H}-1,118-122$ & 41.88 & Mud & Calcite & 94.9 & -7.18 & -14.61 & 15.80 & 113 \\
\hline $6 \mathrm{H}-4,18-22$ & 45.38 & Nodule & Calcite & 98.8 & -9.89 & -14.77 & 15.63 & 114 \\
\hline $6 \mathrm{H}-4,73-76$ & 45.93 & Bulk nodule & Calcite & 96.4 & -20.00 & -9.62 & 20.94 & 68 \\
\hline \multirow[t]{5}{*}{$6 \mathrm{H}-4,73-76$} & 45.93 & Profile: rim & Calcite & & -18.53 & -11.14 & 19.37 & 80 \\
\hline & & rim $\rightarrow$ center & Calcite & & -20.39 & -8.88 & 21.71 & 63 \\
\hline & & center & Calcite & & -21.07 & -8.36 & 22.24 & 59 \\
\hline & & rim $\rightarrow$ center & Calcite & & -22.05 & -11.00 & 19.52 & 79 \\
\hline & & rim & Calcite & & -20.83 & -9.45 & 21.12 & 67 \\
\hline $7 \mathrm{H}-6,11-15$ & 57.81 & Mud & Calcite & 96.6 & -14.35 & -16.99 & 13.35 & 141 \\
\hline $7 \mathrm{H}-\mathrm{CC}, 38-42$ & 59.70 & Nodule & Calcite & 97.0 & -19.33 & -11.43 & 19.08 & 83 \\
\hline $9 \mathrm{H}-3,118-121$ & 73.38 & Nodule & Calcite & 97.4 & -10.58 & -13.04 & 17.42 & 97 \\
\hline $10 X-1,40-43$ & 79.10 & Nodule & Calcite & 97.2 & -9.21 & -12.54 & 17.93 & 92 \\
\hline $10 X-2,13-15$ & 80.33 & Nodule & Calcite & 97.7 & -17.06 & -13.59 & 16.85 & 102 \\
\hline $12 \times-5,14-17$ & 95.84 & Indurated nodule & Calcite & 96.4 & -12.53 & -13.01 & 17.45 & 97 \\
\hline \multirow[t]{4}{*}{$12 X-5,14-17$} & 95.84 & Profile: rim & Calcite & & -11.29 & -13.23 & 17.22 & 99 \\
\hline & & rim->center & Calcite & & -11.60 & -12.50 & 17.98 & 92 \\
\hline & & rim->center & Calcite & & -13.04 & -12.09 & 18.40 & 88 \\
\hline & & center & Calcite & & -15.34 & -11.49 & 19.02 & 83 \\
\hline
\end{tabular}

by bacterial degradation of organic matter, at least in the upper 50$100 \mathrm{~m}$ of the sediments, is also consistent with pore-water geochemical analyses, which show a decrease in sulfate and an increase in alkalinity, phosphate, and ammonium (Davis, Mottl, Fisher, et al., 1992). Below depths of approximately $200 \mathrm{mbsf}$, where temperatures above $100^{\circ}-120^{\circ} \mathrm{C}$ are inferred and where pore-water chemistries show constant sulfate concentrations, sulfate-reducing reactions may no longer be operative, and the carbon isotope compositions are most likely controlled by thermal degradation of organic matter (see Boni et al., this volume).

The oxygen isotope ratios of both calcite and dolomite are similar to normal marine values in the upper $95 \mathrm{~m}$ of sediment, ranging from $-2.1 \%$ to $1.0 \%$ (PDB). Below that they decrease progressively to a $\delta^{18} \mathrm{O}$ value of $-22.9 \%$ (Fig. 4B; Table 4 ). The decrease in $\delta^{18} \mathrm{O}$ values most likely reflects progressively increasing temperatures of carbonate precipitation. Assuming equilibrium with seawater (i.e., $0 \%$ 


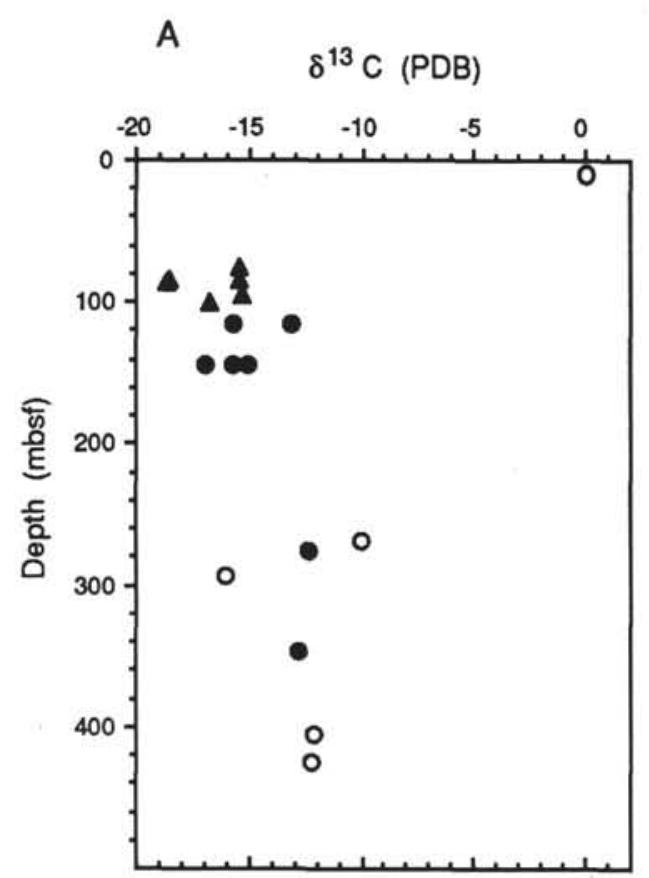

B

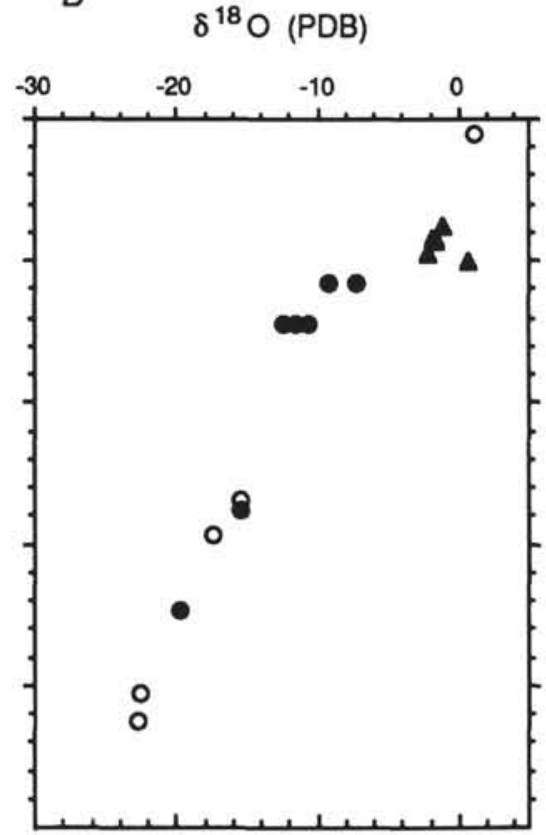

C Temperature $\left({ }^{\circ} \mathrm{C}\right)$

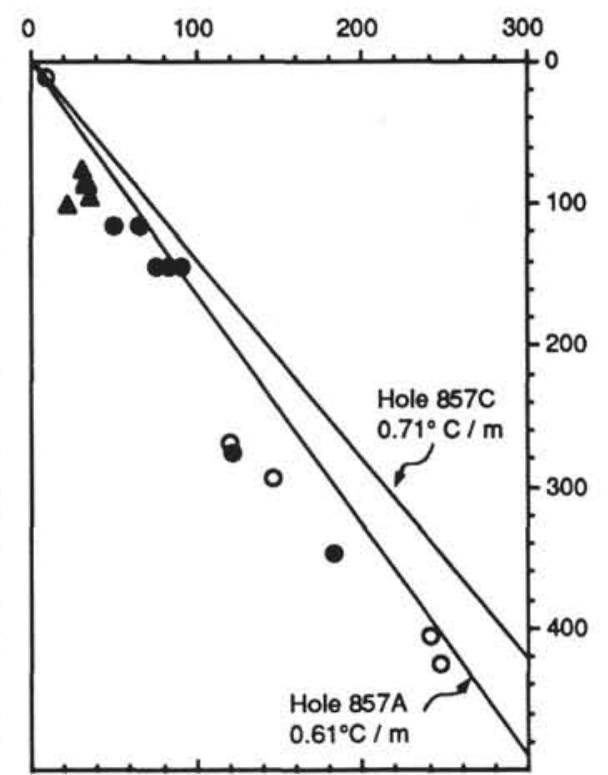

Figure 4. Carbon (A) and oxygen (B) isotope ratios (\%o relative to PDB) of calcite cements (open circles), calcite nodules (filled circles), and dolomite cement and dolomite nodules (filled triangles) as a function of depth from samples from the hydrothermal reservoir at Holes 857A and 857C (see Table 4). C. Calculated temperatures of carbonate formation assuming a seawater isotopic composition of $0.0 \%$ SMOW. The straight lines represent the present-day thermal gradient estimated from in-situ temperature measurements at Holes 857A and 857C (Davis, Mottl, Fisher, et al., 1992).

Table 4. Carbonate compositions, stable isotope data and temperature estimates for samples from the hydrothermal reservoir at Site 857.

\begin{tabular}{|c|c|c|c|c|c|c|c|c|c|c|}
\hline \multirow{2}{*}{$\begin{array}{l}\text { Core, section, } \\
\text { interval }(\mathrm{cm})\end{array}$} & \multirow{2}{*}{$\begin{array}{l}\text { Depth } \\
\text { (mbsf) }\end{array}$} & \multirow{2}{*}{$\begin{array}{l}\text { General sample } \\
\text { description }\end{array}$} & \multirow{2}{*}{$\begin{array}{l}\text { Carbonate } \\
\text { mineralogy }\end{array}$} & \multirow{2}{*}{$\begin{array}{l}\mathrm{CaCO}_{3} \\
(\mathrm{~mol} \%)\end{array}$} & \multirow{2}{*}{$\begin{array}{l}\delta^{18} \mathrm{O} \% \\
(\mathrm{PDB})\end{array}$} & \multirow{2}{*}{$\begin{array}{l}\delta^{18} \mathrm{O} \% \\
(\mathrm{PDB})\end{array}$} & \multirow{2}{*}{$\begin{array}{l}\delta^{18} \mathrm{O} \% \\
(\mathrm{SMOW})\end{array}$} & \multicolumn{2}{|c|}{ Temperature $\left({ }^{\circ} \mathrm{C}\right)$} & \multirow{2}{*}{$\begin{array}{c}\text { Calculated } \\
\delta^{18} \mathrm{O}\left(\mathrm{H}_{2} \mathrm{O}\right)^{\mathrm{c}}\end{array}$} \\
\hline & & & & & & & & calculated $^{\mathrm{a}}$ & measured ${ }^{b}$ & \\
\hline \multicolumn{11}{|l|}{ 139-857A- } \\
\hline $1 \mathrm{H}-7,27-31$ & 11.17 & Mud & Calcite & 100.2 & 0.11 & 1.04 & 31.93 & 9 & 7 & -0.7 \\
\hline $10 \mathrm{H}-5,43-45$ & 85.33 & Weakly indurated mud & Dolomite & 56.4 & -18.48 & -1.59 & 29.22 & 34 & 52 & 3.5 \\
\hline $11 \mathrm{X}-\mathrm{CC}, 22-24$ & 87.29 & Weakly indurated mud & Dolomite & 56.4 & -18.55 & -1.80 & 29.00 & 35 & 53 & 3.5 \\
\hline 11X-CC, $24-26$ & 87.31 & Nodule & Dolomite & 55.8 & -18.56 & -1.50 & 29.32 & 33 & 53 & 3.8 \\
\hline $13 \mathrm{X}-1,1-2$ & 101.51 & Nodule & Dolomite & 51.8 & -16.61 & 0.82 & 31.71 & 23 & 62 & 7.7 \\
\hline \multicolumn{11}{|l|}{$139-857 \mathrm{C}-$} \\
\hline $4 \mathrm{R}-\mathrm{CC}, 2-3$ & 76.12 & Nodule & Dolomite & 53.9 & -15.28 & -1.11 & 29.71 & 32 & 54 & 4.4 \\
\hline $6 \mathrm{R}-1,5-6$ & 86.25 & Indurated sediment & Dolomite & 55.3 & -15.33 & -1.78 & 29.03 & 35 & 61 & 4.9 \\
\hline $7 \mathrm{R}-1,3-4$ & 95.23 & Nodule & Dolomite & 51.8 & -15.15 & -2.06 & 28.74 & 36 & 68 & 5.6 \\
\hline $9 \mathrm{R}-1,10-11$ & 114.91 & Nodule & Calcite & 94.0 & -15.58 & -6.57 & 24.09 & 48 & 82 & 4.8 \\
\hline $9 \mathrm{R}-1,50-51$ & 115.00 & Nodule & Calcite & 93.8 & -13.13 & -9.28 & 21.29 & 66 & 82 & 2.0 \\
\hline $12 \mathrm{R}-1,10-11$ & 143.60 & Nodule & Calcite & 96.2 & -16.91 & -10.58 & 19.95 & 76 & 102 & 3.0 \\
\hline $12 \mathrm{R}-1,48-49$ & 143.98 & Nodule & Calcite & 97.0 & -14.98 & -11.59 & 18.91 & 84 & 102 & 2.0 \\
\hline $12 \mathrm{R}-1,125-126$ & 144.75 & Incipient nodule & Calcite & 96.2 & -15.62 & -12.48 & 17.99 & 92 & 103 & 1.1 \\
\hline $25 \mathrm{R}-1,15-17$ & 268.95 & Inhomogeneous indurated sediment & Calcite & 97.7 & -9.90 & -15.37 & 15.02 & 121 & 191 & 4.9 \\
\hline $26 \mathrm{R}-\mathrm{CC}, 1-3$ & 276.24 & Nodule & Calcite & 97.2 & -12.26 & -15.43 & 14.95 & 122 & 196 & 5.1 \\
\hline $47 R-2,24-26$ & 405.74 & Indurated sediment & Calcite & 98.8 & -12.06 & -22.55 & 7.61 & 241 & 288 & 1.6 \\
\hline $51 \mathrm{R}-1,129-131$ & 424.69 & Inhomogeneous indurated sediment & Calcite & 98.8 & -12.18 & -22.79 & 7.37 & 247 & 302 & 1.7 \\
\hline
\end{tabular}

SMOW), oxygen isotope temperatures range from $9^{\circ} \mathrm{C}$ at nearsurface conditions to approximately $250^{\circ} \mathrm{C}$ at 425 mbsf (Fig. $4 \mathrm{C}$; Table 4). The calculated O-isotope fractionation temperatures show a nearly linear trend that is slightly lower than the present-day geothermal gradients measured at Holes 857A and 857C (Davis, Mottl, Fisher, et al., 1992). The calculated O-isotope temperatures and the in-situ temperature measurements both indicate a high-temperature hydrothermal regime.

The apparent slight difference between measured geothermal gradients and oxygen isotope temperatures could be a result of mixed generations of carbonate that were precipitated as burial and temperatures increased (compare results from Hole 856A; Table 3). Alternatively, the present-day thermal gradient may be higher than that at the time of carbonate formation, or the carbonates may have precipitated from seawater-dominated fluids that were enriched in ${ }^{18} \mathrm{O}$ during high-temperature interaction with the underlying igneous crust (e.g., Craig et al., 1980; Bowers and Taylor, 1985). Calculated values of $\delta^{18} \mathrm{O}_{\mathrm{H}_{2} \mathrm{O}}$ of the precipitating fluids, assuming the measured temperature gradients of $0.61^{\circ} \mathrm{C} / \mathrm{m}$ for Hole $857 \mathrm{~A}$ and $0.71^{\circ} \mathrm{C} / \mathrm{m}$ for Hole 857C (Davis, Mottl, Fisher, et al., 1992), are shown in Table 4. These 
values are considerably more positive than seawater, ranging from approximately $2 \%$ to $5 \%$.

Interestingly, at Site $857 \mathrm{C}$ from approximately $200 \mathrm{~m}$ to $400 \mathrm{mbsf}$, pore-water profiles for chlorinity, sodium, potassium, and calcium are locally anomalous compared to those in the overlying and underlying sediments (Davis, Mottl, Fisher, et al., 1992). The change in porewater chemical composition from that of bottom seawater has been attributed to early diagenetic processes and to water-rock interaction at temperatures in excess of $250^{\circ} \mathrm{C}$ (Ocean Drilling Program Scientific Drilling Party, 1992). These processes produce pore fluids at depths between 300 and 400 mbsf that have concentrations of chlorinity, sodium, potassium, and calcium similar to those of the waters venting at $276^{\circ} \mathrm{C}$ at Site 858 . At this depth interval, the pore fluids may be well mixed and flow laterally through the sediments, providing the source for the vents approximately $1.5 \mathrm{~km}$ away. This is consistent with geochemical analyses of the sediments that show a large enrichment in $\mathrm{Na}_{2} \mathrm{O}$ at these depths and indicate large total fluid fluxes and metasomatic reaction between sediment and pore water (Davis, Mottl, Fisher, et al., 1992). The isotopic signatures of the carbonates may thus reflect this zone of convective hydrothermal flow, in which metasomatic alteration in the sediments, and possibly in the underlying mafic sills, results in an enrichment in ${ }^{18} \mathrm{O}$ of the precipitating fluids. However, fluid fluxes must be sufficiently low relative to reaction rates so that the reactions occurring in the rocks would influence the fluid chemistry.

\section{Active Hydrothermal Field (Site 858)}

Site 858 is an area of active hydrothermal discharge, located approximately $1.6 \mathrm{~km}$ from Site 857 (Fig. 1). Fluids currently discharge at temperatures between $255^{\circ}$ and $275^{\circ} \mathrm{C}$ through numerous vents distributed over an area that extends about $800 \mathrm{~m}$ along and 400 $\mathrm{m}$ across the strike of Middle Valley (Davis, Mottl, Fisher, et al., 1992). A series of four shallow holes (858A-858D) were drilled across the vent field in order to document local fluid flow and thermal regimes as well as hydrothermal alteration in the sediments beneath and around the vent field. Two deeper holes ( $858 \mathrm{~F}$ and $858 \mathrm{G}$ ) drilled approximately in the center of the field penetrated the upper igneous crust. The sedimentary cover at Site 858 consists of turbiditic and hemipelagic sequences, typical of the Middle Valley area, although they are hydrothermally altered. Systematic variations in temperatures, pore fluid compositions, degree of alteration, and sulfide content occur laterally and with depth.

In this study, bulk rock geochemical and stable isotope data of Holes $858 \mathrm{~A}-858 \mathrm{D}$ are combined with mineralogical studies to document the progressive alteration of the sedimentary cover associated with convective fluid flow and hydrothermal discharge under contrasting reducing and oxidizing conditions. The distinct hydrothermal alteration zones recognized at Site 858 reflect a change from hightemperature conditions near the vent sites (Holes $858 \mathrm{~B}$ and $858 \mathrm{D}$ ) to lower temperature conditions at the margins of the discharge conduit (Holes 858A and 858C). Mineralogic zoning as well as bulk chemical data and stable isotope geochemistry of the sediments reflect changes in pore fluid chemistries and fluid flow and thermal regimes. The following discussion is divided into two parts: the first part presents data from the lower temperature distal region of the vent area; the second part discusses the high-temperature alteration at the center of hydrothermal activity.

\section{Distal Region of Active Hydrothermal Vent Field}

Hole $858 \mathrm{~A}$, located approximately $150 \mathrm{~m}$ west of the nearest currently active vent, is the least affected by hydrothermal alteration and contains the most complete background record of hemipelagic and turbiditic sedimentation at this site. The bulk sediment geochemistries at Hole $858 \mathrm{~A}$ are comparable to those at the distal holes at the former discharge area at Site 856 (Tables 1 and 2) and reflect the min- eralogical interlayering and mixture of detrital and hydrothermal phases (see Buatier et al., this volume). The detrital continental contribution as well as a lack of basaltic components in Hole 858 A is well defined in the plot of $\mathrm{Fe} / \mathrm{Ti}$ vs. $\mathrm{Al} /(\mathrm{Al}+\mathrm{Fe}+\mathrm{Mn}$ ) (Bostrom, 1973), shown in Figure 2. As at Site 856, the dominant detrital input at Hole $858 \mathrm{~A}$ masks the hydrothermal geochemical signatures.

Hydrothermal activity at the distal area of discharge is characterized by a vertical zonation of alteration minerals. The upper section of sediments (from approximately 10 to $80 \mathrm{mbsf}$ ) represents a carbonatepyrite-smectite alteration zone that contains calcite concretions, disseminated pyrite and pyrite concretions. The carbonate concretions disappear below approximately $65 \mathrm{mbsf}$, whereas disseminated pyrite continues to the bottom of the hole ( $338 \mathrm{mbsf}$ ). Cathodoluminescence microscopy shows that most of the carbonate in both the sediments and the concretions consists of a uniform, bright red-orange luminescing authigenic calcite. Foraminifers are partially preserved to depths of 110 mbsf, but cathodoluminescence studies indicate that these are progressively recrystallized and are infilled with the bright orange, authigenic calcite. XRD analysis indicates low Mg-calcite compositions (Table 5) and electron microprobe studies show enrichments in Mn concentrations (Table 5 in Buatier et al., this volume).

The phyllosilicate assemblages change with depth and degree of induration. Smectite, illite, and chlorite are dominant above approximately $30 \mathrm{mbsf}$ and are detrital on the basis of scanning electron microscope (SEM) studies and hydrogen isotope ratios (Table 6; see also Buatier et al., this volume). An increase in induration and alteration below approximately $35 \mathrm{mbsf}$ is associated with the disappearance of smectite and the appearance of swelling chlorite. At depths below approximately $100 \mathrm{mbsf}$, chlorite is the dominant authigenic clay. Illite content decreases with depth, but is present throughout the hole.

Hole $858 \mathrm{C}$, located $70 \mathrm{~m}$ west of the nearest currently active vent, contains a similar carbonate-pyrite-smectite alteration zone in the upper approximately $16 \mathrm{~m}$ of sediments. A zone of anhydrite-pyritechlorite alteration occurs directly below the carbonate alteration zone in Holes $858 \mathrm{~A}$ and $858 \mathrm{C}$. This zone is characterized by anhydrite in veins and as euhedral crystals or concretions in weakly to moderately indurated claystone (Davis, Mottl, Fisher, et al., 1992). Brecciation is common in this zone in Hole $858 \mathrm{C}$. The anhydrite-pyrite-chlorite assemblages grade into a zone of silicious, higher-temperature alteration in the core of the upflow zone. This zone is characterized by well-indurated, chloritized, and fractured sediments that are cut by quartz-albite veins with varying pyrite concentrations.

The carbon isotope ratios of the calcite cement and calcite nodules from Holes $858 \mathrm{~A}$ and $858 \mathrm{C}$ reflect two main sources of carbonate carbon (Figs. 5A and 5B). Methane oxidation is indicated by $\delta^{13} \mathrm{C}$ values between $-33.5 \%$ and $-29.4 \%$ in the nodules closest to the surface (ca. 11-12 mbsf) in Hole 858A (e.g., Claypool and Kaplan, 1974; Coleman et al., 1981; Ritger et al., 1987). These nodules also have the highest ${ }^{18} \mathrm{O}$ values ( $3.2 \%$ to $4.4 \%$ [PDB] ), which indicate low temperatures of formation. One carbonate nodule in Hole $858 \mathrm{C}$ at $47 \mathrm{mbsf}$ (Sample 139-858C-8H-CC, 0-3 cm) has similar isotopic compositions which could reflect low temperature methane oxidation associated with brecciation in the anhydrite alteration zone. However, it is possible that this sample originated higher up in the section and represents drilling rubble (Davis, Mottl, Fisher, et al., 1992). Most of the other samples at these two holes have $\delta^{13} \mathrm{C}$ values ranging from approximately $-24.2 \%$ to $-7.9 \%$ (Table 5), similar to values for the carbonates at the other sites, and indicate an organic matter source of carbonate carbon.

With the exception of the nodules that record methanogenesis, the oxygen isotope ratios of the carbonates are depleted in ${ }^{18} \mathrm{O}$ relative to normal marine carbonates (Fig. 5B). In Hole 858A, the $\delta^{18} \mathrm{O}$ values vary between $-17.1 \%$ and $-9.4 \%$ (PDB), with no distinct correlation with depth. The carbonates in Hole $858 \mathrm{C}$ have a large range of $\delta^{18} \mathrm{O}$ values over small differences in depth, varying from near-marine compositions of $-1.3 \%$ to values of $-10.7 \%$ (Table 5). A depletion in ${ }^{18} \mathrm{O}$ is common to all of the studied sites and most likely reflects 


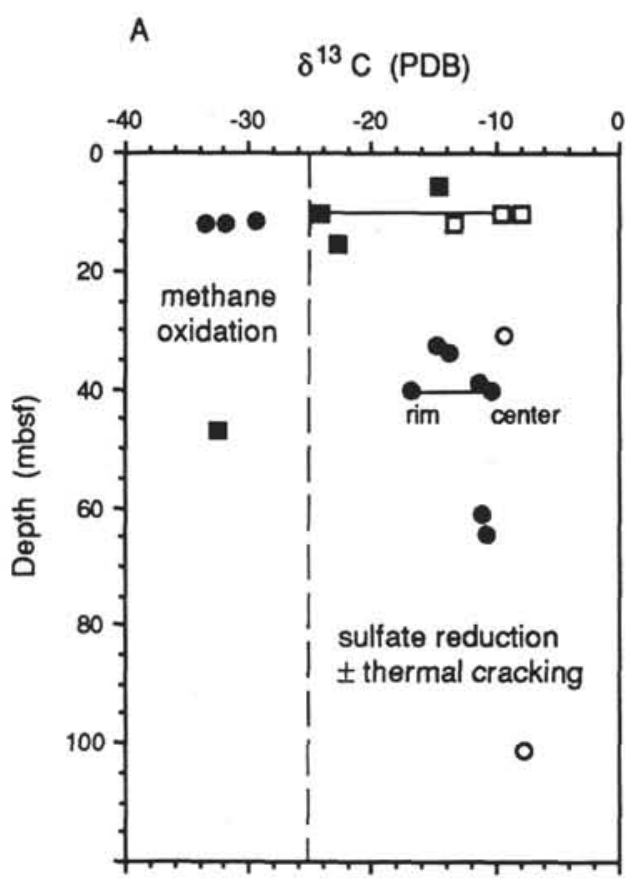

B

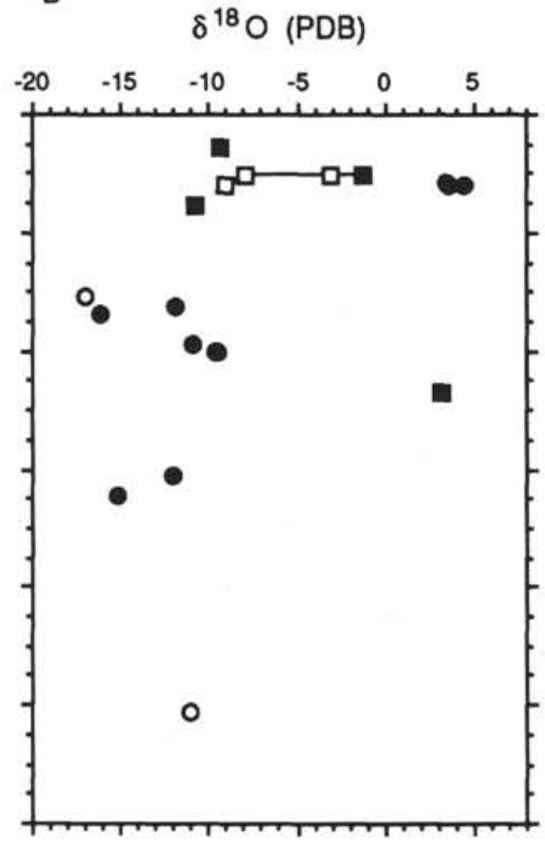

C

Temperature $\left({ }^{\circ} \mathrm{C}\right)$

Figure 5. Carbon (A) and oxygen (B) isotope ratios (\%o relative to PDB) of calcite cements (open symbols) and calcite nodules (filled symbols) as a function of depth from samples from the distal discharge region at Hole $858 \mathrm{~A}$ (circles) and Hole $858 \mathrm{C}$ (squares). The tie-lines represent sediment and nodule compositions or rim-center compositions from the same sample (see Table 5). C. Calculated temperatures of carbonate formation assuming a seawater isotopic composition of $0.0 \%$ SMOW. The lines A and C represent the present-day thermal gradient estimated from in-situ temperature measurements at Holes $858 \mathrm{~A}$ and $858 \mathrm{C}$, respectively (Davis, Mottl, Fisher, et al., 1992).

elevated temperatures of carbonate precipitation. An increase in temperature with depth is also indicated by progressively negative $\delta^{18} \mathrm{O}$ values of the clay-size fractions from Hole 858A (Table 6; Fig. 6). Temperatures of up to about $80^{\circ} \mathrm{C}$ at $10-15$ mbsf in Hole $858 \mathrm{C}$ and $145^{\circ} \mathrm{C}$ at $30-35$ mbsf in Hole $858 \mathrm{~A}$ have been calculated from the oxygen isotope ratios of the carbonates, assuming equilibrium with seawater with a $\delta^{18} \mathrm{O}$ value of $0 \%$ SMOW (Fig. 5C). Interestingly, the estimated oxygen isotope fractionation temperatures are generally higher than in-situ temperature measurements in the two holes (Davis, Mottl, Fisher, et al., 1992).

Only two samples at Hole 858A were analyzed for hydrogen isotope composition. The shallowest sample at $5.76 \mathrm{mbsf}$ (Sample 139$858 \mathrm{~A}-2 \mathrm{H}-3,36-40 \mathrm{~cm}$ ) containing a mixed chlorite + smectite + illite assemblage has $\mathrm{D} / \mathrm{H}$ ratios of $-84 \%$ (SMOW) and is clearly detrital (see Buatier et al., this volume). In contrast, the $\delta \mathrm{D}$ value of the nearly pure sample of chlorite at 266 mbsf (Sample 139-858A-31X-2, 3-5 $\mathrm{cm})$ is $-44 \%$ and is similar to average $\delta \mathrm{D}$ values of authigenic clays from Hole $858 \mathrm{~B}$ (discussed subsequently), indicating a strong seawater component of hydrogen in the hydrothermal fluid (Table 6).

A complex history of dissolution and precipitation reactions, diffusion, and advection is reflected in the pore-water profiles and mineralogical zones at Holes 858A and 858C (Davis, Mottl, Fisher, et al., 1992). The large range in oxygen isotope ratios over nearly the same depth interval, as well as distinct differences in isotopic compositions between nodule and host sediment in Sample 139-585A-5H-CC, $10-11 \mathrm{~cm}$, and between center and rim in Sample 139-858C-2H-5, $71-73 \mathrm{~cm}$, (Table 5) indicate a lack of isotopic equilibrium and suggest that the temperatures and/or the oxygen isotope composition of the precipitating fluids have changed during the evolution of the sediments. Shallow-level advection and lateral flow of high-temperature fluids could have produced the relatively high-temperature carbonate authigenesis observed between 15 and 35 mbsf in Holes $858 \mathrm{~A}$ and $858 \mathrm{C}$. Pore-water geochemical analyses in Hole $858 \mathrm{C}$ show maximum chlorinity at 19 mbsf and maximum calcium concentrations at about $30 \mathrm{mbsf}$, suggesting that advection of fluids has

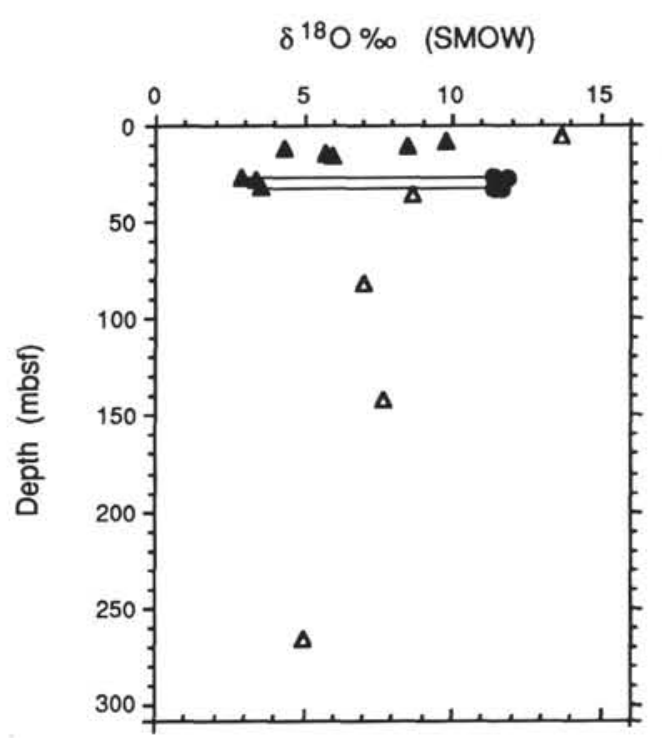

Figure 6. Oxygen isotope ratios of clay-size fraction (triangles) and authigenic quartz (circles) as a function of depth from samples from the central discharge region at Hole 858A (open symbols) and Hole 858B (filled symbols). The tie-lines represent compositions of corrensite-quartz and chlorite-quartz pairs from the same sample (see Table 6).

occurred or is occurring at these shallow depths. Alternatively, these concentration maxima may be unrelated and may reflect two different processes: diffusion resulting from a glacial-to-interglacial change in the chlorinity of bottom seawater (Imbrie et al., 1984) and calcite dissolution at shallow depths (Davis, Mottl, Fisher, et al., 1992). The fact that the carbon and oxygen isotope compositions have not homogenized at the higher temperatures suggests short-lived hydrothermal 
Table 5. Carbonate compositions, stable isotope data, and temperature estimates for samples from the active discharge region at Site 858 .

\begin{tabular}{|c|c|c|c|c|c|c|c|c|}
\hline $\begin{array}{l}\text { Core, section, } \\
\text { interval }(\mathrm{cm})\end{array}$ & $\begin{array}{l}\text { Depth } \\
\text { (mbsf) }\end{array}$ & $\begin{array}{c}\text { General sample } \\
\text { description }\end{array}$ & $\begin{array}{l}\text { Carbonate } \\
\text { mineralogy }\end{array}$ & $\begin{array}{l}\mathrm{CaCO}_{3} \\
(\mathrm{~mol} \%)\end{array}$ & $\begin{array}{c}\delta^{13} \mathrm{C} \% \\
(\mathrm{PDB})\end{array}$ & $\begin{array}{c}\delta^{18} \mathrm{O} \% \\
(\mathrm{PDB})\end{array}$ & $\begin{array}{l}\delta^{18} \mathrm{O} \% \\
\text { (SMOW) }\end{array}$ & $\begin{array}{c}\text { Temperature } \\
\left({ }^{\circ} \mathrm{C}\right)^{\mathrm{a}}\end{array}$ \\
\hline \multicolumn{9}{|l|}{ 139-858A- } \\
\hline $2 \mathrm{H}-7,30-31$ & 11.70 & Nodule & Calcite & 97.9 & -29.38 & 3.48 & 34.44 & 0 \\
\hline $2 \mathrm{H}-7,40-42$ & 11.80 & Nodule & Calcite & & -31.79 & 3.56 & 34.53 & -1 \\
\hline $3 \mathrm{H}-1,0-3$ & 11.90 & Nodule & Calcite & 97.2 & -33.50 & 4.39 & 35.39 & -4 \\
\hline $4 \mathrm{H}-7,15-17$ & 30.55 & Weakly indurated mud & Calcite & 99.0 & -9.31 & -17.08 & 13.25 & 142 \\
\hline $5 \mathrm{H}-2,2-4$ & 32.42 & Nodule & Calcite & & -14.90 & -11.90 & 18.59 & 87 \\
\hline $5 \mathrm{H}-2,134-137$ & 33.74 & Nodule & Calcite & 98.8 & -13.75 & -16.18 & 14.18 & 130 \\
\hline $5 \mathrm{H}-6,40-45$ & 38.80 & Nodule & Calcite & & -11.33 & -10.88 & 19.64 & 78 \\
\hline $5 \mathrm{H}-\mathrm{CC}, 10-11$ & 40.00 & Nodule: center & Calcite & & -10.36 & -9.59 & 20.97 & 68 \\
\hline $5 \mathrm{H}-\mathrm{CC}, 10-11$ & 40.00 & Nodule: rim & Calcite & & -16.89 & -9.44 & 21.13 & 67 \\
\hline $8 \mathrm{H}-2,57-59$ & 60.90 & Nodule & Calcite & 97.6 & -11.10 & -12.02 & 18.47 & 88 \\
\hline $9 X-2,61-64$ & 64.61 & Nodule & Calcite & & -10.76 & -15.21 & 15.18 & 119 \\
\hline $14 \mathrm{X}-\mathrm{CC}, 11-13$ & 101.11 & Weakly indurated mud & Calcite & & -7.81 & -11.09 & 19.43 & 80 \\
\hline \multicolumn{9}{|l|}{ 139-858B- } \\
\hline $1 \mathrm{H}-2,129-133$ & 2.79 & Mud & Calcite & 99.8 & -0.24 & 1.38 & 32.28 & 88 \\
\hline $1 \mathrm{H}-5,34-36$ & 6.34 & Mud & Calcite & 99.0 & -7.30 & -4.26 & 26.47 & 35 \\
\hline \multicolumn{9}{|l|}{$139-858 \mathrm{C}$ - } \\
\hline $2 \mathrm{H}-2,39-41$ & 5.39 & Nodule & Calcite & 90.2 & -14.54 & -9.39 & 21.18 & 67 \\
\hline $2 \mathrm{H}-5,56-58$ & 10.06 & Mud & Calcite & 99.0 & -7.91 & -3.09 & 27.67 & 28 \\
\hline $2 \mathrm{H}-5,71-73$ & 10.30 & Weakly indurated mud & Calcite & 99.1 & -9.50 & -7.92 & 22.69 & 57 \\
\hline $2 \mathrm{H}-5,71-73$ & 10.30 & Nodule & Calcite & 99.1 & -24.19 & -1.28 & 29.54 & 20 \\
\hline $2 \mathrm{H}-6,81-83$ & 11.81 & Mud & Calcite & 97.7 & -13.42 & -9.04 & 21.54 & 64 \\
\hline $3 \mathrm{H}-2,100-115$ & 15.50 & Brecciated nodule & Calcite & 100.1 & -22.76 & -10.70 & 19.83 & 77 \\
\hline $8 \mathrm{H}-\mathrm{CC}, 0-3$ & 47.17 & Nodule & Calcite & 97.0 & -32.47 & 3.23 & 34.19 & 1 \\
\hline \multicolumn{9}{|l|}{$139-858 \mathrm{D}$} \\
\hline $1 \mathrm{H}-1,72-75$ & 0.72 & Indurated mud & Calcite & 96.5 & -31.50 & 2.86 & 33.81 & 2 \\
\hline 1H-5, 75-77 & 6.75 & Nodule & Calcite & & -14.66 & -8.78 & 21.81 & 62 \\
\hline $2 \mathrm{H}-1,92-94$ & 10.22 & Mud & Dolomite & 56.7 & -6.79 & -9.74 & 20.82 & 83 \\
\hline $2 \mathrm{H}-2,44-46$ & 11.24 & Weakly indurated mud & Dolomite & 55.5 & -9.11 & -11.37 & 19.14 & 97 \\
\hline $2 \mathrm{H}-3,101-103$ & 13.31 & Indurated mud & Dolomite & 51.5 & -11.26 & -10.10 & 20.45 & 86 \\
\hline $2 \mathrm{H}-4,86-88$ & 14.66 & Indurated mud & Calcite & 98.0 & -16.68 & -16.67 & 13.68 & 136 \\
\hline $2 \mathrm{H}-4,99-101$ & 14.79 & Mud & Calcite & & -16.60 & -17.06 & 13.28 & 141 \\
\hline $2 \mathrm{H}-5,80-82$ & 16.10 & Mud & Calcite & 97.7 & -18.64 & -19.14 & 11.13 & 172 \\
\hline $4 \mathrm{H}-1,5-7$ & 19.85 & Indurated mud & Calcite & 92.0 & & & & \\
\hline \multirow[t]{3}{*}{$4 \mathrm{H}-1,5-7$} & 19.85 & Profile: rim & Calcite & & -17.61 & -6.88 & 23.77 & 50 \\
\hline & & rim $\rightarrow$ center & Calcite & & -17.40 & -7.04 & 23.60 & 51 \\
\hline & & rim & Calcite & & -17.30 & -6.70 & 23.95 & 49 \\
\hline $4 \mathrm{H}-1,11-13$ & 19.91 & Nodule & Calcite & 91.2 & -16.93 & -8.63 & 21.96 & 61 \\
\hline \multirow[t]{4}{*}{$4 \mathrm{H}-1,11-13$} & 19.91 & Profile: rim & Calcite & & -17.07 & -8.61 & 21.99 & 61 \\
\hline & & rim $\rightarrow$ center & Calcite & & -16.90 & -8.50 & 22.10 & 60 \\
\hline & & center & Calcite & & -17.47 & -8.64 & 21.95 & 61 \\
\hline & & center $\rightarrow$ rim & Calcite & & -16.48 & -8.63 & 21.97 & 61 \\
\hline $4 \mathrm{H}-2,18-20$ & 20.22 & Indurated mud & Calcite & & -19.50 & -19.57 & 10.69 & 179 \\
\hline $4 \mathrm{H}-2,28-30$ & 20.32 & Nodule & Calcite & 94.3 & -32.36 & 3.17 & 34.13 & 1 \\
\hline $4 \mathrm{H}-2,78-80$ & 20.78 & Nodule & Calcite & 93.6 & -32.54 & 3.30 & 34.27 & 0 \\
\hline $7 \mathrm{X}-\mathrm{CC}, 1-3$ & 37.20 & Indurated mud & Calcite & 92.3 & -21.13 & -1.74 & 29.07 & 22 \\
\hline \multicolumn{9}{|l|}{$139-858 \mathrm{E}(\mathrm{F})-$} \\
\hline $2-\mathrm{CC}, 0-5$ & & Nodule & Calcite & 97.0 & -27.78 & 2.53 & 33.47 & 3 \\
\hline
\end{tabular}

a Temperatures estimated from calcite-water fractionation factors of Clayton et al. (1972) and dolomite-water fractionation factors of Matthews and Katz (1977), assuming an unaltered seawater $\delta^{18} \mathrm{O}$ value of $0 \%$ (SMOW).

episodes and would explain the apparent differences between measured and estimated temperatures.

\section{Central Discharge Region of Active Hydrothermal Field (Holes $858 \mathrm{~B}$ and $858 \mathrm{D})$}

Holes $858 \mathrm{~B}$ and $858 \mathrm{D}$ are located in the immediate vicinity of hydrothermal vents and show high-temperature alteration and mineralization associated with the discharge of hydrothermal fluids. Hole $858 \mathrm{~B}$ was drilled $140 \mathrm{~m}$ west of Hole $857 \mathrm{C}$ and only a few meters from a hydrothermal vent that discharges fluids at $286^{\circ} \mathrm{C}$. This shallow hole (drilled to a depth of $38.6 \mathrm{mbsf}$ ) is characterized by a welldefined, vertical metasomatic zonation, which is reflected in the mineral parageneses, bulk chemical composition, and stable isotope compositions. Hole 858D was drilled to a depth of $40.7 \mathrm{mbsf}$ and is located approximately $70 \mathrm{~m}$ northeast of the nearest vent at Hole $858 \mathrm{~B}$. This hole consists predominantly of fine-grained hemipelagic sediments with thin beds of turbiditic silt, and is distinctly more carbonaceous than Hole $858 \mathrm{~B}$.

The mineralogy of the sediments at Hole $858 \mathrm{~B}$ is characterized by a dominance of authigenic phases. Sulfidic, clay-rich sediments occur at the top, followed by a pyrite + clay layer, grading into a zone of semimassive sulfides with anhydrite, and finally a $\mathrm{Mg}$ corrensite-rich layer overlies corrensite-talc-chlorite-rich sediments at the bottom. Detailed mineralogical studies of clay-size fractions show a distinct change in silicate mineralogies with depth (Buatier et al., this volume). Smectite is dominant in the upper $11 \mathrm{mbsf}$, whereas $\mathrm{Mg}$-rich corrensite, swelling chlorite, and/or chlorite are commonly the major components below approximately $12.4 \mathrm{mbsf}$. Authigenic quartz, identified by SEM studies, coexists with corrensite in Section 139-858B$5 \mathrm{H}-3$ (at $27.5 \mathrm{mbsf}$ ) and with chlorite in Section 139-858B-6H-1 (at $32 \mathrm{mbsf}$ ). Carbonate is rare in this hole and was only found in samples of fine-grained sediments closest to the sediment/water interface (Core 139-858B-1H).

The bulk chemical compositions of samples studied from Hole $858 \mathrm{~B}$ emphasize the mineralogical layering and the precipitation of hydrothermal phases in this hole (Tables 1 and 2). For example, the $\mathrm{Si} / \mathrm{Al}$ and $\mathrm{Si} / \mathrm{Mg}$ ratios are controlled by quartz content and the abundance of Si- and $\mathrm{Mg}$-rich authigenic phases, and are highest in the authigenic layers that are enriched in phyllosilicates (Fig. 7). The authigenic origin of the $\mathrm{Mg}$-silicates is well expressed by the $\mathrm{Mg}$ content in the bulk sediments and the pore-water $\mathrm{Mg}$ concentrations (Davis, Mottl, Fisher, et al., 1992), shown in Fig. 8. Mg concentrations in the pore waters decrease from $44.9 \mathrm{mmol} / \mathrm{kg}$ to $12.7 \mathrm{mmol} / \mathrm{kg}$ 


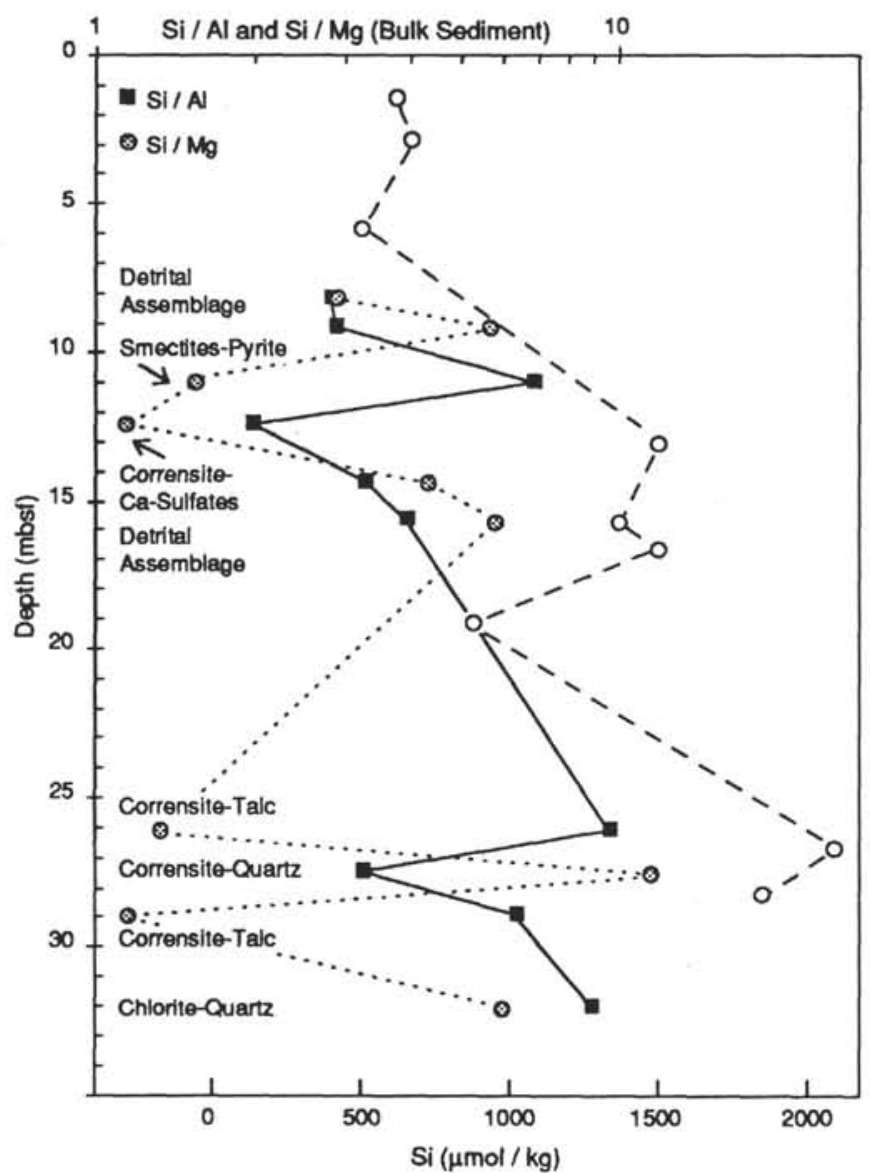

Figure 7. Variation of $\mathrm{Si} / \mathrm{Al}$ and $\mathrm{Si} / \mathrm{Mg}$ ratios vs. depth in sediments from Hole $858 \mathrm{~B}$ and changes in $\mathrm{Si}$ concentration (open circles) in pore water with depth (pore-water data from Davis, Mottl, Fisher, et al., 1992).

between 10 and $13 \mathrm{mbsf}$ and correlate directly with the precipitation of Mg-corrensite (see Tables 7 and 8 in Buatier et al., this volume). Very high $\mathrm{Ca}$ - and $\mathrm{Fe}$-contents correspond to the layers rich in hydrothermal sulfates and Fe-sulfides. Sulfate precipitation is also marked by high $\mathrm{Sr}$ contents in the bulk sediments of up to $940 \mathrm{ppm}$, whereas the Fe-sulfide layers show enrichments in $\mathrm{Zn}$ and $\mathrm{Cu}$ (Table 2; Fig. 9). Furthermore, enrichments in $\mathrm{Ba}$ and $\mathrm{Sr}$ (Fig. 9) are associated with the precipitation of quartz in the purely hydrothermal layer containing quartz, chlorite, and corrensite (Sample 139-858B-5H-3, 58-62).

Oxygen isotope ratios of the clay-size fractions from Hole $858 \mathrm{~B}$ decrease from a $\delta^{18} \mathrm{O}$ value of $9.8 \%$ (SMOW) at $9.15 \mathrm{mbsf}$ to values between $2.9 \%$ and $3.6 \%$ in samples of authigenic corrensite and/or chlorite below $27.5 \mathrm{mbsf}$ (Fig. 6; Table 6). Hydrogen isotope ratios are relatively constant, with $\delta \mathrm{D}$ between $-46 \%$ and $-44 \%$ (SMOW) throughout the hole, and suggest a slightly altered seawater source of hydrogen in the hydrothermal fluid. The systematic depletion in ${ }^{18} \mathrm{O}$ with depth clearly reflects the high thermal gradients that prevail at this hole. These data also clearly show the difference in geothermal gradients between the central discharge regions of Hole $858 \mathrm{~B}$ and the more distal regions of the vent field at Hole 858A.

Although data on the oxygen isotope fractionation between chlorite and water is limited, a first approximation of equilibrium temperatures can be made from the preliminary experimental data of Cole (1985). Savin and Lee (1988) have shown that at temperatures between approximately $150^{\circ}$ and $400^{\circ} \mathrm{C}$, the experimental chloritewater curve of Cole is similar to those estimated on the basis of bondtype calculations for Fe-bearing chlorites. Thus, by combining this chlorite-water oxygen isotope fractionation data and the quartz-water fractionation data of Clayton et al. (1972), an equilibrium temperature

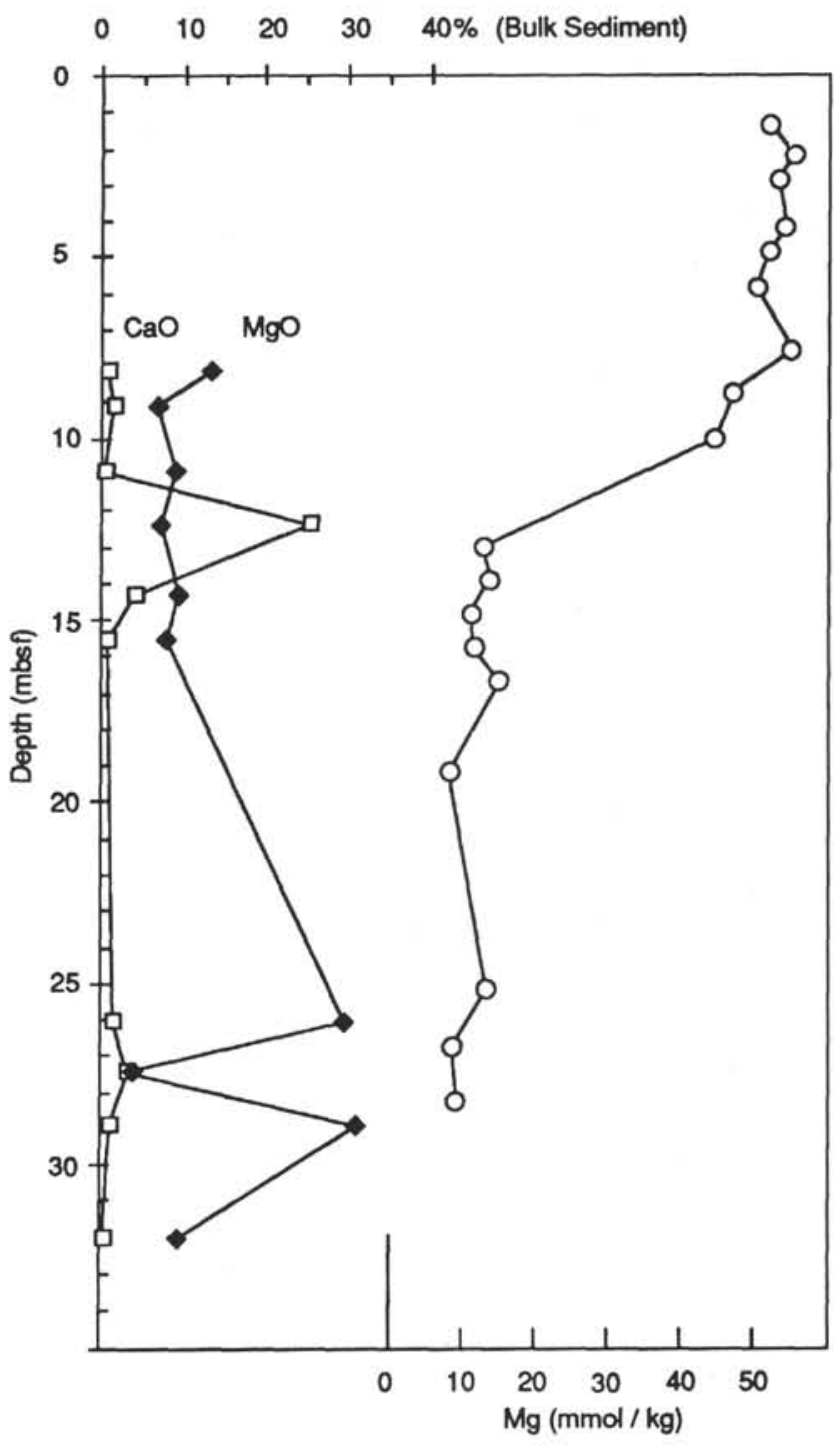

Figure 8. Variation of $\mathrm{CaO}$ and $\mathrm{MgO}$ contents (in wt\%) vs. depth in sediments from Hole $858 \mathrm{~B}$ and changes in $\mathrm{Mg}$ concentration (open circles) in pore water with depth (pore-water data from Davis, Mottl, Fisher, et al., 1992).

can be estimated for the authigenic chlorite-quartz pair measured from Hole $858 \mathrm{~B}$. This method gives an approximate temperature of $265^{\circ} \mathrm{C}$ at $32 \mathrm{mbsf}$ and fits well with the temperature gradient estimated by carbonate isotope data from the adjacent Hole $858 \mathrm{D}$ (discussed subsequently; see also Fig. 10).

Hole $858 \mathrm{D}$ is distinguished mineralogically from the immediate vent area, Hole $858 \mathrm{~B}$, by the presence of a carbonate-rich zone at the top of the hole. This zone is similar to the carbonate-pyrite-smectite alteration zone in Holes $858 \mathrm{~A}$ and $858 \mathrm{C}$ and contains carbonate cement and nodules in the upper $20-30 \mathrm{~m}$ of sediments. Fine-grained pyrite occurs as euhedral disseminated grains or in concretions and burrows between 10 and 30 mbsf (Davis, Mottl, Fisher, et al., 1992). Dolomite is the dominant carbonate phase between approximately 10 and $14 \mathrm{mbsf}$ and occurs as cement in the weakly to moderately indurated, fine-grained sediments (Buatier et al., this volume; Davis, Mottl, Fisher, et al., 1992). XRD studies of samples directly above and below the dolomite-rich zone show low Mg-calcite compositions, whereas samples from Core 139-858D-4H (below approximately $19 \mathrm{mbsf}$ ) have high- $\mathrm{Mg}$ calcite with up to 8.8 mole $\% \mathrm{MgCO}_{3}$ (Table 5).

As at Holes $858 \mathrm{~A}$ and $858 \mathrm{C}$, the carbonate-pyrite-smectite zone grades into an anhydrite-pyrite-chlorite zone of alteration in Section 
Table 6. Mineralogy and stable isotope data of clay-size samples from the active discharge region at Site 858 .

\begin{tabular}{|c|c|c|c|c|c|}
\hline $\begin{array}{l}\text { Core, section, } \\
\text { interval }(\mathrm{cm})\end{array}$ & $\begin{array}{l}\text { Depth } \\
\text { (mbsf) }\end{array}$ & Mineralogy $y^{\mathrm{a}}$ & $\begin{array}{l}\text { Grain size } \\
\quad(\mu \mathrm{m})\end{array}$ & $\begin{array}{c}\delta \mathrm{D} \% 0 \\
(\mathrm{SMOW})\end{array}$ & $\begin{array}{l}\delta^{18} \mathrm{O} \% \\
\text { (SMOW) }\end{array}$ \\
\hline $\begin{array}{l}139-856 \mathrm{~A}- \\
\quad 1 \mathrm{H}-1,48-51\end{array}$ & 0.48 & $\mathrm{SM}+\mathrm{chl}+\mathrm{Ill}$ & $<2$ & -98 & 13.7 \\
\hline $\begin{array}{l}139-858 \mathrm{~A}- \\
2 \mathrm{H}-3,36-40 \\
5 \mathrm{H}-4,27-30 \\
12 \mathrm{X}-\mathrm{CC}, 14-15 \\
18 \mathrm{X}-2,132-134 \\
31 \mathrm{X}-2,3-5\end{array}$ & $\begin{array}{r}5.76 \\
35.67 \\
81.94 \\
142.42 \\
266.17\end{array}$ & $\begin{array}{c}\text { chl }+ \text { sm }+ \text { ill } \\
\text { sw-chl }+ \text { ill } \\
\text { ill }+ \text { sw-chl } \\
\text { CHL }+ \text { ill } \\
\text { CHL } \pm \text { ill }\end{array}$ & $\begin{array}{l}<2 \\
<2 \\
<2 \\
<2 \\
<2\end{array}$ & $\begin{array}{l}-84 \\
-44\end{array}$ & $\begin{array}{r}13.7 \\
8.7 \\
7.1 \\
7.7 \\
5.0\end{array}$ \\
\hline $\begin{array}{l}139-858 \mathrm{~B}- \\
2 \mathrm{H}-2,45-47 \\
2 \mathrm{H}-3,75-77 \\
2 \mathrm{H}-4,72-74 \\
2 \mathrm{H}-5,113-115 \\
2 \mathrm{H}-6,89-91 \\
5 \mathrm{H}-3,58-62 \\
5 \mathrm{H}-3,58-62 \\
5 \mathrm{H}-3,58-62 \\
5 \mathrm{H}-4,55-59 \\
6 \mathrm{H}-1,51-53 \\
6 \mathrm{H}-151-53 \\
6 \mathrm{H} 151-53\end{array}$ & $\begin{array}{r}9.15 \\
10.95 \\
12.42 \\
14.33 \\
15.59 \\
27.48 \\
27.48 \\
27.48 \\
28.95 \\
32.01 \\
32.01 \\
32.01\end{array}$ & $\begin{array}{c}\mathrm{Sm}+\mathrm{chl}+\mathrm{ill} \\
\mathrm{SM} \pm \mathrm{chl} \\
\mathrm{CORR} \pm \mathrm{sw}-\mathrm{chl} \\
\mathrm{Chl} \pm \mathrm{sw}-\mathrm{chl} \pm \mathrm{cm} \pm \text { ill } \\
\mathrm{CHL}+\mathrm{ill} \\
\text { CORR } \\
\text { Authigenic qtz } \\
\text { Authigenic qtz } \\
\text { CORR } \pm \text { talc } \\
\mathrm{CHL} \pm \text { sw-chl } \pm \text { talc } \\
\text { Authigenic qtz } \\
\text { Authigenic qtz }\end{array}$ & $\begin{aligned} & <2 \\
& <2 \\
& <2 \\
& <2 \\
& <2 \\
& <2 \\
10 & \leq x \leq 20 \\
& \geq 20 \\
& <2 \\
& <2 \\
2 & \leq x \leq 10 \\
& \geq 10\end{aligned}$ & $\begin{array}{l}-46 \\
-40 \\
-39 \\
-42\end{array}$ & $\begin{array}{r}9.8 \\
8.5 \\
4.4 \\
5.8 \\
6.0 \\
2.9 \\
11.7 \\
11.4 \\
3.4 \\
3.6 \\
11.4 \\
11.5\end{array}$ \\
\hline
\end{tabular}

${ }^{\text {a }} \mathrm{Sm}=$ smectite $; \mathrm{chl}=$ chlorite ill = illite; $\mathrm{sw}$-chl = swelling chlorite; corr = corrensite; qtz = quartz .

Capitalized mineral abbreviations represent major phyllosilicate phase (see Buatier et al., this volume).

139-858D-4H-3. Anhydrite occurs as concretions of radiating crystals and as coarsely crystalline veins. Sphalerite and sphalerite-zeolite veins with minor chalcopyrite occur in Section 139-858D-6X-1, close to the bottom of the hole at about 30 mbsf (Davis, Mottl, Fisher, et al., 1992). Similar alteration zones were observed in Hole $858 \mathrm{~F}$, which was drilled within $10 \mathrm{~m}$ of Hole $858 \mathrm{D}$ and penetrated $249 \mathrm{~m}$ of sediment before intersecting basalt. Because recovery was poor $(2.74 \%)$, the depths at which these alteration zones occur cannot be considered representative; however, it was clear that Hole $858 \mathrm{~F}$ intersected a heterogeneous zone of highly fractured, brecciated, and veined sediments. In this zone, fractures and small faults are partly filled with quartz and zeolite (wairakite and analcime) veins with minor epidote, pyrite, and sphalerite. Anhydrite occurs locally with quartz \pm zeolites as fracture-filling, vugs, or concretions. Zeolites are rare below approximately 114 mbsf (i.e., below Core 139-858F-11R) and are followed by an increase in albitic plagioclase and chlorite to the bottom of the hole (Davis, Mottl, Fisher, et al., 1992).

The carbon and oxygen isotope ratios of the carbonates in the central vent area are distinct from those of Holes $858 \mathrm{~A}$ and $858 \mathrm{C}$ at the more distal regions of the hydrothermal field (see Figs. 10A and 10B; Table 5). At Hole 858D, nearly linear depletions in ${ }^{13} \mathrm{C}$ and ${ }^{18} \mathrm{O}$ occur to a depth of about 20 mbsf. Nodules sampled at and below this depth have ratios that appear to be similar to samples from higher up in the section. Similar to Holes $858 \mathrm{~A}$ and $858 \mathrm{C}$, the carbon isotope compositions indicate two main sources of carbonate carbon. One surface sample and two nodules at 20.3 and 20.7 mbsf have $\delta^{13} \mathrm{C}$ values between $-32.5 \%$ and $-31.5 \%$ (PDB), which are indicative of methane oxidation. Most of the other samples are similar to the carbonates at the other sites, with $\delta^{13} \mathrm{C}$ values ranging from approximately $-21.1 \%$ to $-6.8 \%$ (Table 5 ), and could reflect carbonate carbon derived either from sulfate reduction or from thermal cracking of hydrocarbons. Alternatively, the nearly linear trend of decreasing $\delta^{13} \mathrm{C}$ may be the result of mixing of isotopically light carbon derived from methane oxidation and marine carbonate with $\delta^{13} \mathrm{C}$ values close to $0 \%$. The decrease in $\delta^{18} \mathrm{O}$ values with depth most likely reflects an increase in formation temperatures during hydrothermal activity and is consistent with the steep temperature gradients inferred at Hole 858B (Fig. 10C; Table 5). Assuming a fluid composition of $0 \%$, estimates of oxygen isotope fractionation temperatures show a nearly linear increase in temperature to $180^{\circ} \mathrm{C}$ at 20 mbsf.

The nodules sampled at and below $19.9 \mathrm{mbsf}$ have high $\mathrm{Mg}$-calcite compositions (Table 5) and have distinctly higher $\delta^{18} \mathrm{O}$ values, indica- tive of lower temperatures of precipitation. Two of these nodules have $\delta^{13} \mathrm{C}$ values that indicate methane oxidation and near-surface conditions. The exact depths of these nodules may be unreliable because drilling disturbances occurred in Core 139-858D-4H, with "soupy" textures in Sections 139-858D-4H-1 and 139-858D-4H-2 (Davis, Mottl, Fisher, et al., 1992). The fact that these nodules occur in the upper meter of Core 139-858D-4H further suggests that they represent misplaced drilling rubble that fell from above into the core barrel. In addition, the samples from Core 139-858D-7X-CC can likewise be considered downhole contamination, representing drilling breccia.

\section{CONCLUSIONS}

\section{Middle Valley Convective Hydrothermal Circulation}

The isotopic and geochemical study of authigenic precipitates and pore fluids associated with the active hydrothermal system at Site 858 provides an analogue for former hydrothermal systems, such as those at Site 856, and can be used to develop a hydrothermal circulation model based on an integration of isotope, mineralogical, bulk chemi$\mathrm{cal}$, and pore-water data. Site 858 represents one arm of a convective hydrothermal circulation cell (Fig. 11). The overall trend is for cooler seawater to be drawn into the sediments in the vicinity of Holes $858 \mathrm{~A}$ and $858 \mathrm{C}$ to replace hot water that is moving upward and venting in the vicinity of Holes $858 \mathrm{~B}$ and $858 \mathrm{D}$, and $858 \mathrm{~F}$. This large-scale convective circulation cell apparently drives smaller-scale fluid advection and causes near-surface seawater recharge, which is demonstrated by the precipitation of dolomite between 10 and $15 \mathrm{mbsf}$ at Hole 858D. The pore-water geochemistry between 0 and 20 mbsf at Hole $858 \mathrm{D}$ indicates a flux of $\mathrm{Mg}$ from the surface to the site of dolomite precipitation with a corresponding increase in $\mathrm{Ca}$. Thus, larger-scale convective circulation cells are established over wide areas, but smaller-scale recharge in the sediments can occur even within the apparent hydrothermal vent zone. Increasing $\mathrm{Ca}$ contents of the hydrothermal fluids below approximately 100 mbsf in Hole $858 \mathrm{~A}$ may also reflect an upward flux of $\mathrm{Ca}$ released during the albiti-zation of feldspar in the underlying sediments, whereas concurrent chloritization depletes $\mathrm{Mg}$ in the pore waters in contact with the same sediments. At the direct vent area at Hole $858 \mathrm{~B}, \mathrm{Mg}$ concentrations in the pore fluids is controlled by the precipitation of $\mathrm{Mg}$-rich phyllosilicates (Fig. 8). Local changes in pore-water concentrations of other species such as chlorinity and dissolved sulfate and silica at Site 858 further indicate that the chemical compositions of the hydrothermal fluid record a complex history of 
bacterial and thermal degradation of organic matter, water-rock interactions, dissolution/precipitation reactions, diffusion, and advection.

The oxygen isotope data for the authigenic carbonates trace the inflow of cooler water and its heating with circulation to greater depths. The isotope thermal gradients calculated for the distal holes of the active hydrothermal system (Holes $858 \mathrm{~A}$ and $858 \mathrm{C}$; Fig. 5) are approximately $2.2^{\circ} \mathrm{C} / \mathrm{m}$, whereas the calculated gradient in the vicinity of the vent area (Holes 858B and 858D; Figs. 10 and 11 ) is approximately $9^{\circ} \mathrm{C}-10^{\circ} \mathrm{C} / \mathrm{m}$. Two temperatures measured at about $20 \mathrm{mbsf}$ track this gradient (Davis, Mottl, Fisher, et al., 1992). An isotope temperature of about $265^{\circ} \mathrm{C}$ for an authigenic clay sample from 32 mbsf at Hole $858 \mathrm{~B}$ indicates that this gradient remains constant to a greater depth in the section. If the gradient were extended even deeper, temperatures as hot as $350^{\circ} \mathrm{C}$ are possible at a relative shallow depth of $35 \mathrm{mbsf}$ within the vent area. Such high temperatures are approaching values sufficient to generate ore-forming fluids. If this potential exists, then the lack of extensive massive sulfides at Site 858 probably reflects the immaturity of this relatively recent hydrothermal system.

The presence of authigenic calcite and dolomite in Holes 858B and $858 \mathrm{D}$ may simply be a fortuitous consequence of this immaturity because as the ore body develops there would be a tendency for the carbonates to be removed and the isotope temperature record of the fluid circulation would be lost. Thus, the isotope temperatures calculated for both the recharge and venting components of the active system at Site 858 provide us with a real-time record of the fluid flow within the present convective hydrothermal circulation cell.

The carbon isotope data for the authigenic carbonates characterize in-situ reactions with organic carbon and can be used to distinguish whether the fluids are oxidizing or reducing (Fig. 11). In Holes 858A, $858 \mathrm{C}$, and $858 \mathrm{D}$ (Figs. 5 and 10 ), carbonates with negative $\delta^{13} \mathrm{C}$ values of about $-30 \%$ or less at shallow depths $(12 \mathrm{mbsf})$ probably represent the oxidation of isotopically light methane gas. This gas is produced in the underlying sediments and migrates upward to shallow depths, where it encounters advecting or recharging seawater that contains oxygen. In the same holes at Site 858 , the carbonate cements and nodules with $\delta^{13} \mathrm{C}$ values between about $-10 \%$ and $-25 \%$ may contain some methane-generated carbonate but could also be a byproduct of sulfate reduction reactions that would occur in reducing solutions. Depending upon the temperature, the reaction may be either biogenically or thermogenically produced, but, in either case, it would occur under oxygen-depleted conditions. At temperatures above $100^{\circ} \mathrm{C}$, processes of thermal decomposition of organic matter may also provide a significant source of carbonate carbon in the sediments.

The lateral and vertical distribution of the mineralogically distinct alteration zones further reflects the overall convective hydrothermal circulation at Site 858 . The hydrothermal fluids are strongly reducing directly at the vent regions and precipitate $\mathrm{Mg}$-silicates, sulfides, and minor sulfates. Away from the vents, the reducing fluids migrate outward from the discharge conduits and are mixed with more oxidizing fluids, producing the more extensive, thicker carbonate and sulfate mineral zones at the distal regions (Fig. 11). Local mixing between warmer and cooler as well as oxidizing and reducing fluids in the distal regions is consistent with both carbon and oxygen isotope data, which show large variations and a lack of isotopic equilibrium over small changes in depth.

From this study an actualistic model can be derived and used to interpret the isotope and geochemical record of past fluid flow in former hydrothermal systems, such as at Site 856 . The isotopic compositions of the authigenic carbonates in the distal zone of the former hydrothermal circulation cell at Hole 856A give an isotope temperature gradient of about $1.5^{\circ}-2^{\circ} \mathrm{C} / \mathrm{m}$. This gradient is similar to that recorded at Holes $858 \mathrm{~A}$ and $858 \mathrm{C}$, but is higher than the measured modern gradient at either Hole $856 \mathrm{~A}\left(0.50^{\circ} \mathrm{C} / \mathrm{m}\right)$ or Hole $856 \mathrm{~B}\left(1.27^{\circ} \mathrm{C} / \mathrm{m}\right)$ (Davis, Mottl, Fisher, et al., 1992). It appears that even though the system is now inactive, the isotopic composition of the carbonates continues to record the previous thermal gradient as well as special fluid flow conditions

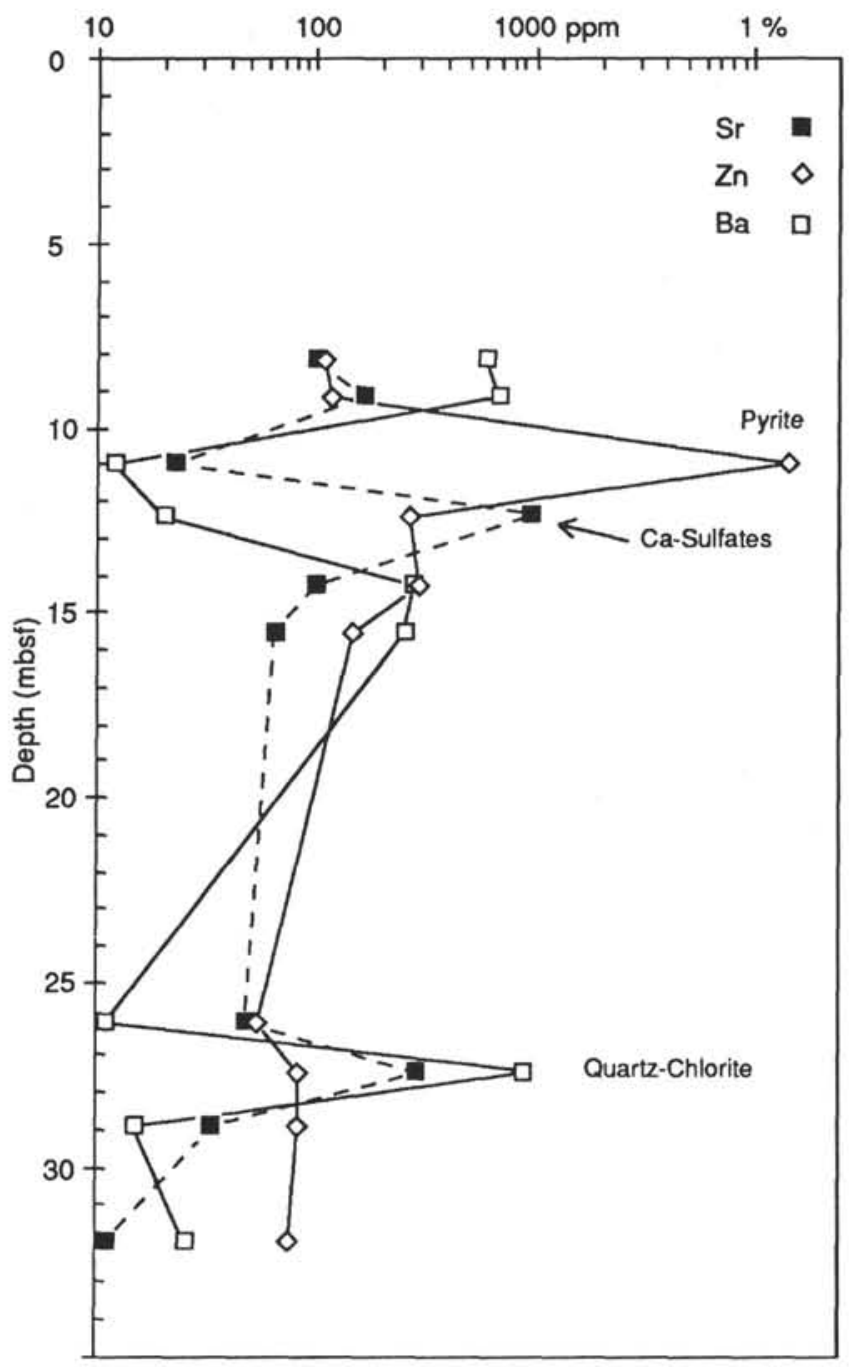

Figure 9. Variation of $\mathrm{Sr}, \mathrm{Zn}$, and Ba contents (in ppm) vs. depth in sediments from Hole 858B.

within the sedimentary sequence at Site 856 related to the intrusion of a sill between 40 and 60 mbsf, as discussed previously. The retention of the $\delta^{18} \mathrm{O}$ values in the former hydrothermal system at Site 856 allows for a comparison with the active system at Site 858. This comparison could provide valuable information to help define the hydrothermal circulation pattern in ancient economic deposits.

\section{Rate of Fluid Flow vs. Water/Rock Interaction}

The shipboard-measured pore-water geochemistry traces the evolution of the circulating fluids from initial normal, cold, oxidizing seawater entering the sediments into a hot reducing fluid capable of generating a massive sulfide ore body (Davis, Mottl, Fisher, et al., 1992). Undoubtedly, mineral reactions along the fluid path control the pore-water geochemistry, and geochemical alterations lead to a paragenetic sequence of authigenic minerals forming in the sediments, which marks the fluid pathways. This study demonstrates that the oxygen isotope record stored in these authigenic phases can be used to calculate temperature gradients in both the active and fossil hydrothermal systems. These calculations were based on the assumption that the isotopic composition of the circulating seawater remained unchanged, but this basic assumption is probably not correct. Our stable isotope data strongly imply that the fluid/rock interactions significantly alter the isotopic composition of the hydrothermal fluids. 

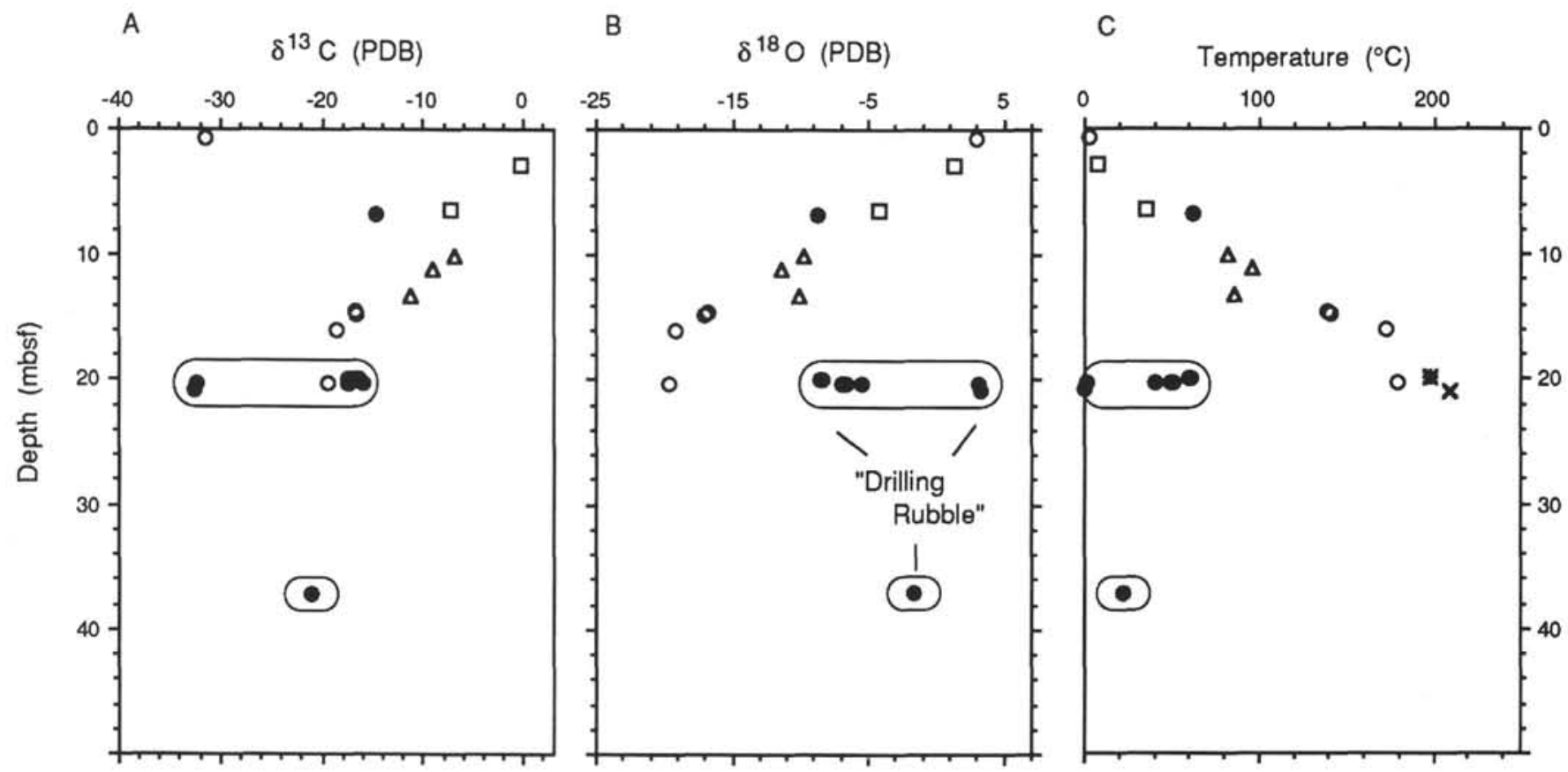

Figure 10. Carbon (A) and oxygen (B) isotope ratios (in \%o relative to PDB) of calcite and cements (open symbols) and calcite nodules (filled symbols) as a function of depth from samples from the central discharge region at Hole 858B (squares) and Hole 858D (circles). Dolomite cement (open triangles) occurs solely in Hole 858D. C. Calculated temperatures of carbonate formation assuming a seawater isotopic composition of $0.0 \%$ SMOW. Only two reliable in-situ temperature measurements were made in these holes: $197^{\circ} \mathrm{C}$ at $19.5 \mathrm{mbsf}$ in Hole $858 \mathrm{~B}$ (star) and approximately $208^{\circ} \mathrm{C}$ at $20.9 \mathrm{mbsf}$ in $\mathrm{Hole} 858 \mathrm{D}$ (x).

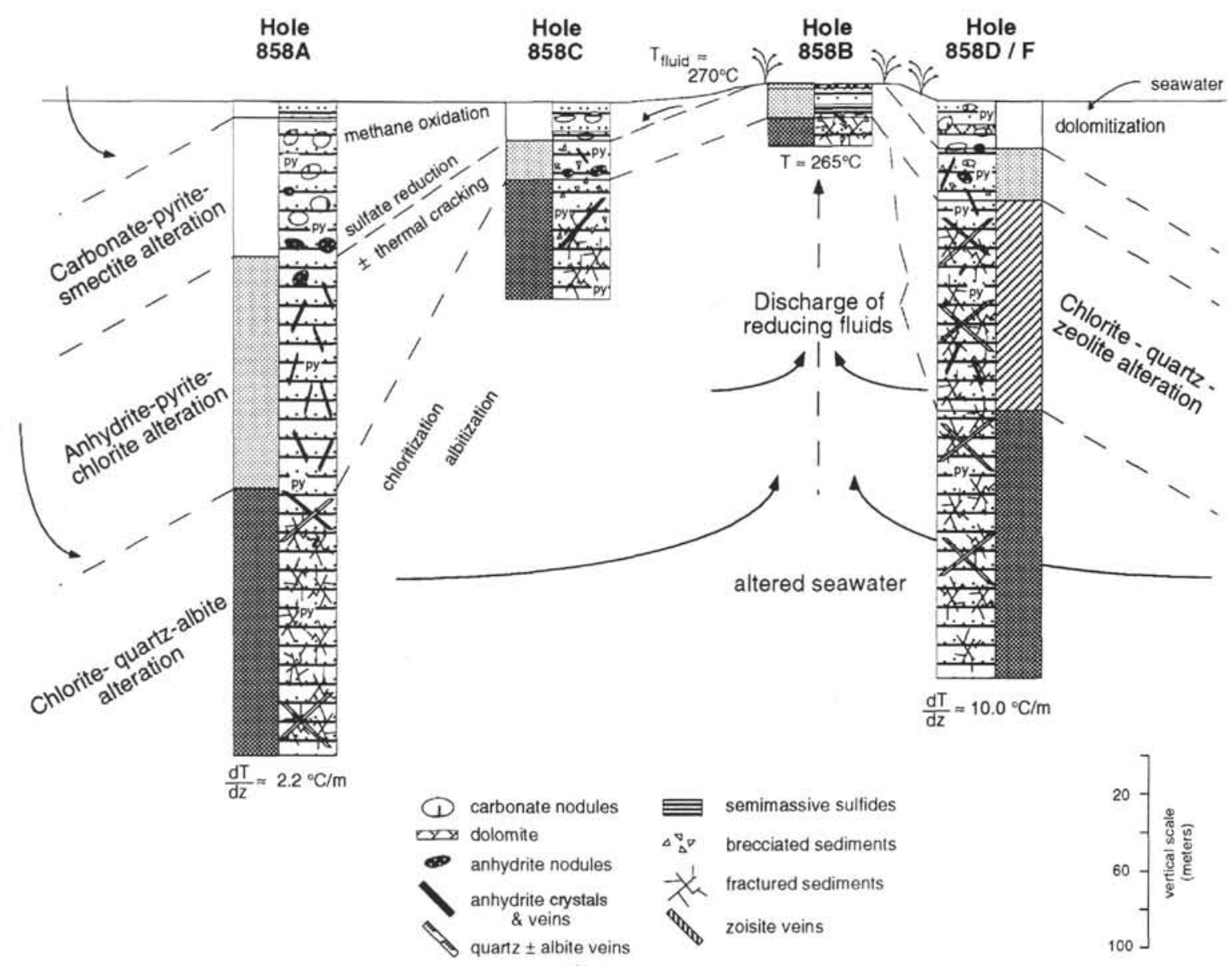

Figure 11. Schematic diagram (modified after Davis, Mottl, Fisher, et al., 1992) depicting lithologic variations, mineralogic hydrothermal alteration zones of the sedimentary cover, and convective hydrothermal circulation inferred from geochemical and stable isotope data at Site 858 (see text for discussion). No horizontal scale is inferred. 
The geothermal gradient at Site 857, the hydrothermal reservoir, was measured between $0.61^{\circ}$ and $0.71^{\circ} \mathrm{C} / \mathrm{m}$ (Davis, Mottl, Fisher, et al., 1992). Temperatures derived from this gradient were used to calculate the isotopic composition of the fluids in equilibrium with the authigenic carbonates secured from the upper $420 \mathrm{~m}$ of the sedimentary sequence (Table 4). These calculations indicate that the hydrothermal fluids were enriched in ${ }^{18} \mathrm{O}$ relative to normal seawater with a shift in $\delta^{18} \mathrm{O}$ toward positive values between $1 \%$ and $5 \%$. An isotopic enrichment of the fluids can likewise be demonstrated using data for the quartz-chlorite pair sampled at Hole 858B, the hydrothermal vent area. With these data, a temperature of $265^{\circ} \mathrm{C}$ was calculated. This temperature, in turn, can be used to estimate the $\delta^{18} \mathrm{O}$ values of the fluids from which the quartz precipitated. Again, the calculations indicate an enrichment in ${ }^{18} \mathrm{O}$ to an $\delta^{18} \mathrm{O}$ value of about $2.6 \%$. Based on these two indirect calculation methods, we conclude that an isotopic alteration of circulating seawater probably occurred.

In order to alter the isotopic composition of the circulating fluid, the reaction rates must be high relative to the fluid flux rates. As other lines of geochemical evidence indicate that voluminous amounts of water must be flowing through the system to produce observed changes in the sediments, we conclude that the isotopic exchange between the circulating fluids and the rock must be very rapid. In other words, the alteration of the $\mathrm{d}^{18} \mathrm{O}$ values of the fluids is consistent with an extremely reactive thermal system with a vigorous fluid flux.

\section{ACKNOWLEDGMENTS}

We would like to express our gratitude to A. Fallick and T. Donnelly at the Scottish Universities Reactor and Research Centre for hydrogen analyses and to $\mathrm{C}$. Vasconcelos for help with carbonate sample preparation and isotope analyses. The geochemical analytical work was performed at the Centre de Géochimie de la Surface (CNRS), Strasbourg. This manuscript benefited greatly from discussions with S. Bernasconi and J. Connolly and from thorough and constructive reviews by $\mathrm{M}$. Goldhaber and S. Savin. This study was supported by ETH grant No. 0-20-014-90 to G.F.G; Swiss NFS grant No. 20-29'052.90 to J.A.M.; INSU-IST grant No. 91GEO2/3.06 to M.B. and A.M.K.; and CNR grants A.I.05.9205478 and CTB 1993-M.B. Cita to M. Boni.

\section{REFERENCES ${ }^{*}$}

Al-Aasm, I.S., and Blaise, B., 1991. Interaction between hemipelagic sediment and a hydrothermal system: Middle Valley, northern Juan de Fuca Ridge, subarctic northeast Pacific. Mar. Geol., 98:25-40.

Besnus, Y., and Rouault, R., 1973. Une méthode d'analyse de roches au spectromètre d'arc à lecture directe par un dispositif d'électrode rotative. Analusis, 2:111-116.

Borthwick, J., and Harmon, R.S., 1982. A note regarding $\mathrm{CIF}_{3}$ as an alternative to $\mathrm{BrF}_{5}$ for silicate oxygen isotope analysis. Geochim. Cosmochim. Acta. 46:1665-1668.

Boström, K., 1970. Submarine volcanism as a source of iron. Earth Planet. Sci. Lett., 9:348-354.

, 1973. The origin and fate of ferromanganoan active ridge sediments. Stockholm Contrib. Geol., 27:149-243.

1983. Genesis of ferromanganese deposits - diagnostic criteria for recent and old deposits. In Rona, P.A., et al. (Eds.), Hydrothermal Processes at Seafloor Spreading Centers. NATO Conf. Ser. IV, 12:473-489.

Boström, K., and Peterson, M.N.A., 1969. The origin of aluminium-poor ferromanganoan sediments in areas of high heat flow on the East Pacific Rise. Mar. Geol., 7:427-447.

Bowers, T.S., and Taylor, H.P., Jr., 1985. An integrated chemical and stable isotope model of the origin of midocean ridge hot spring systems. $J$. Geophys. Res., 90:12583-12606.

Claypool, G.E., and Kaplan, I.R., 1974. The origin and distribution of methane in marine sediments. In Kaplan, I.R. (Ed.), Natural Gases in Marine Sediments: New York (Plenum), 99-139.

Clayton, R.N., O'Neil, J., and Mayeda, T.K., 1972. Oxygen isotope exchange between quartz and water. J. Geophys. Res., 77:3057-3067.
Cole, D.R., 1985. A preliminary evaluation of oxygen isotopic exchange between chlorite and water. Geol. Soc. Am. Abstr. Programs, 17:550.

Coleman, M.L., Risatti, J.B., and Schoell, M., 1981. Fractionation of carbon and hydrogen isotopes by methane-oxidizing bacteria. Geochim. Cosmochim. Acta, 45:1033-1037.

Craig, H., Welhan, J.A., Kim, K., Poreda, R., and Lupton, J.E., 1980. Geochemical studies of the $21^{\circ} \mathrm{N}$ EPR hydrothermal fluids. Eos, 61:992.

Davis, E.E., Goodfellow, W.D., Bornhold, B.D., Adshead, J., Blaise, B., Villinger, H., and Le Cheminant, G.M., 1987. Massive sulfides in a sedimented rift valley, northern Juan de Fuca Ridge. Earth Planet. Sci. Lett., 82:49-61.

Davis, E.E., and Lister, C.R.B., 1977. Tectonic structures on the Juan de Fuca Ridge. Geol. Soc. Am. Bull., 88:346-363.

Davis, E.E., Mottl, M.J., Fisher, A.T., et al., 1992. Proc. ODP, Init. Repts., 139: College Station, TX (Ocean Drilling Program).

Davis, E.E., and Villinger, H., 1992. Tectonic and thermal structure of the Middle Valley sedimented rift, northern Juan de Fuca Ridge. In Davis, E.E., Mottl, M.J., Fisher, A.T., et al., Proc. ODP, Init. Repts., 139: College Station, TX (Ocean Drilling Program), 9-41.

Friedman, I., and O'Neil, J., 1977. Compilation of stable isotope fractionation factors of geochemical interest. In Fleischer, M. (Ed.), Data of Geochemistry (6th Ed.). Geol. Surv. Prof. Pap. U.S., 440-KK:1-12.

Goldsmith, J.R., and Graf, D.L., 1958. Relations between lattice constraints and composition of the Ca-Mg carbonates. Am. Mineral., 43:84-101.

Goodfellow, W.D., and Blaise, B., 1988. Sulfide formation and hydrothermal alteration of hemipelagic sediment in Middle Valley, northern Juan de Fuca Ridge. Can. Mineral., 26:675-696.

Imbrie, J., Hays, J.D., Martinson, D.G., McIntyre, A., Mix, A.C., Morley, J.J., Pisias, N.G., Prell, W.L., and Shackleton, N.J., 1984. The orbital theory of Pleistocene climate: support from a revised chronology of the marine delta $\delta^{18} \mathrm{O}$ record. In Berger, A., Imbrie, J., Hays, J., Kukla, G., and Saltzman, B. (Eds.), Milankovitch and Climate (Pt. 1): Dordrecht (D. Reidel), 269-305.

Jørgensen, B.B., Isaksen, M.F., and Jannasch, H.W., 1992. Bacterial sulfate reduction above $100^{\circ} \mathrm{C}$ in deep-sea hydrothermal vent sediments. Science, 258:1756-1757.

Lumsden, D.N., 1979. Discrepancy between thin section and X-ray estimates of dolomite in limestone. J. Sediment. Petrol., 49:429-436.

Machel, H.G., 1987. Some aspects of diagenetic sulphate-hydrocarbon redox reactions. In Marshall, J.D. (Ed.), Diagenesis of Sedimentary Sequences. Geol. Soc. Spec. Publ. London, 36:15-28.

Matthews, A., and Katz, A., 1977. Oxygen isotope fraction during the dolomitization of calcium carbonate. Geochim. Cosmochim. Acta, 41:1431-1438.

McCrea, J.M., 1950. The isotopic chemistry of carbonates and a paleotemperature scale. J. Chem. Phys., 18:849-857.

Ocean Drilling Program Leg 139 Scientific Drilling Party, 1992. Hot rocks and massive sulfides: northern Juan de Fuca Ridge. Eos, 73:193.

O'Neil, J.R., Clayton, R.N., and Mayeda, T.K., 1969. Oxygen isotope fractionation in divalent metal carbonates. J. Chem. Phys., 51:5547-5558.

Raiswell, R., 1987. Non-steady state microbiological diagenesis and the origin of concretions and nodular limestones. In Marshall, J.D. (Ed.), Diagenesis of Sedimentary Sequences. Geol. Soc. Spec. Publ. London, 36:41-54.

Ritger, S., Carson, B., and Suess, E., 1987. Methane-derived authigenic carbonates formed by subduction-induced pore water expulsion along the Oregon/Washington margin. Geol. Soc. Am. Bull., 98:147-156.

Samuel, J., Rouault, R., and Besnus, Y., 1985. Analyse multiélémentaire standardisée des matériaux géologiques en spectrométrie d'emission par plasma à couplage inductif. Analusis, 13:312-317.

Savin, S.M., and Lee, M., 1988. Isotopic studies of phyllosilicates. In Bailey, S.W. (Ed.), Hydrous Phyllosilicates (Exclusive of Micas). Min. Soc. Am., Rev. Mineral., 19:189-223.

Sharma, T., and Clayton, R.N., 1965. Measurement of ${ }^{18} \mathrm{O} /{ }^{16} \mathrm{O}$ ratios of total oxygen in carbonates. Geochim. Cosmochim. Acta, 29:1347-1353.

\footnotetext{
Abbreviations for names of organizations and publications in ODP reference lists follow the style given in Chemical Abstracts Service Source Index (published by American Chemical Society).
}

Date of initial receipt: 30 November 1992

Date of acceptance: 15 June 1993

Ms 139SR-217 